\title{
Long-term monitoring and analyses of physical factors regulating variability in coastal Antarctic phytoplankton biomass, in situ productivity and taxonomic composition over subseasonal, seasonal and interannual time scales
}

\author{
Mark A. Moline*, Barbara B. Prézelin \\ Primary Production Group, Department of Ecology, Evolution and Marine Biology and the Marine Science Institute,
} University of California, Santa Barbara, California 93106 USA

\begin{abstract}
A 3 yr high-resolution temporal data base related to phytoplankton dynamics was collected during the austral spring/summer periods of 1991 to 1994 in shelf waters adjacent to Palmer Station, Antarctica. Here, the data base is used (1) to quantrfy the variability in phytoplankton biomass, in situ productivity and taxonomic composition over subseasonal, seasonal and interannual time scales; (2) to elucidate environmental mechanisms controlling these temporal patterns; and (3) to ascertain which phytoplankton markers are most suitable for detecting longer-term (i.e. decadal) trends in phytoplankton dynamics in coastal waters of the Southern Ocean. The Long-Term Ecological Research (LTER) coastal study sites showed high interannual variabilıty in peak phytoplankton biomass (75 to $494 \mathrm{mg}$ chl $\left.\mathrm{a} \mathrm{m}^{-2}\right)$ and integrated primary production (1.08 to $\left.6.58 \mathrm{~g} \mathrm{C} \mathrm{m}^{-2} \mathrm{~d}^{-1}\right)$. Seasonal and annual patterns in biomass and productivity were shown to be driven by shorter-time-scale physical forcing by local wind stress. Low daily wind speeds $\left(<10 \mathrm{~m} \mathrm{~s}^{-1}\right)$ were associated with water-column stabilization. However, extended periods ( $>1 \mathrm{wk}$ ) of low wind stress were required for increased phytoplankton growth and biomass accumulation. Temperature data supports the view that water masses can be replaced on time scales of a less than a day to a few days in these coastal waters. Such disruptions are associated with abrupt changes in local primary production and may lead to sudden shifts in local phytoplankton community structure. Despite the high seasonal and interannual variability in biomass and associated in situ productivity in this coastal environment, the replacement sequence of one dominant phytoplankton group by another was very similar on subseasonal time scales for all 3 years. We suggest that changes in phytoplankton successional patterns may be a more sensitive marker for detecting long-term trends in Southern Ocean ecosystems than either biomass or productivity indices, where short-term variability of the latter is as great or greater than interannual variations documented to date.
\end{abstract}

KEY WORDS: Phytoplankton - Biomass - Primary production - Interannual variability - Seasonal variability - Taxonomic succession Southern Ocean

\section{INTRODUCTION}

There has been a concerted effort in the past decade to integrate physical, chemical, and biological data in an attempt to understand the mechanisms controlling phytoplankton bloom dynamics in the Southern Ocean

\footnotetext{
- Present address: Institute of Marine and Coastal Sciences, Rutgers University, New Brunswick, New Jersey 08903-0231. USA.E-mail:moline@ahab.rutgers.edu
}

(Smith \& Nelson 1985, Lancelot et al. 1991a, b, Mitchell \& Holm-Hansen 1991, Sakshaug et al. 1991, Mathot et al. 1992, Smetacek et al. 1992, Scharek et al. 1994, De Baar et al. 1995, Smith et al. 1995, Turner \& Owens 1995). These studies were conducted shipboard in pelagic regions and focused on the spatial variability of phytoplankton distribution, abundance, productivity, and physiology related to the respective physical and chemical environments. Enhanced biomass and productivity have been found to be associated with frontal regions, mar- 
ginal ice edge zones and coastal regions. Theoretical and empirical models derived from such studies suggest that water column stability, grazing and/or resource limitation are the major factors governing phytoplankton bloom dynamics. While these studies have advanced the understanding of the mechanisms controlling phytoplankton dynamics, they have also pointed to the need for better temporal resolution of these processes (HolmHansen et al. 1989, Mitchell \& Holm-Hansen 1991).

Few studies have examined the temporal variability in biomass and primary productivity in the Southern Ocean, and those that have (Horne et al. 1969, Bienati \& Comes 1971, Whitaker 1982, Krebs 1983, Satoh et al. 1986, Domanov \& Lipski 1990, Rivkin 1991) are generally based on a limited number of environmental parameters and/or lack sufficient resolution to track seasonal variations. Recent analyses of sampling frequency effects on error estimates of primary production for coastal Antarctic regions (Moline \& Prézelin 1996) show that the above sampling regimes are not sufficient to resolve significant short-timescale variations in local primary production and may lead to errors in seasonal estimates as high as $50 \%$. These potential errors have significant ramifications for interpretation of seasonal and interannual dynamics and, more importantly, for identifying and quantifying the mechanisms controlling the seasonal pat-

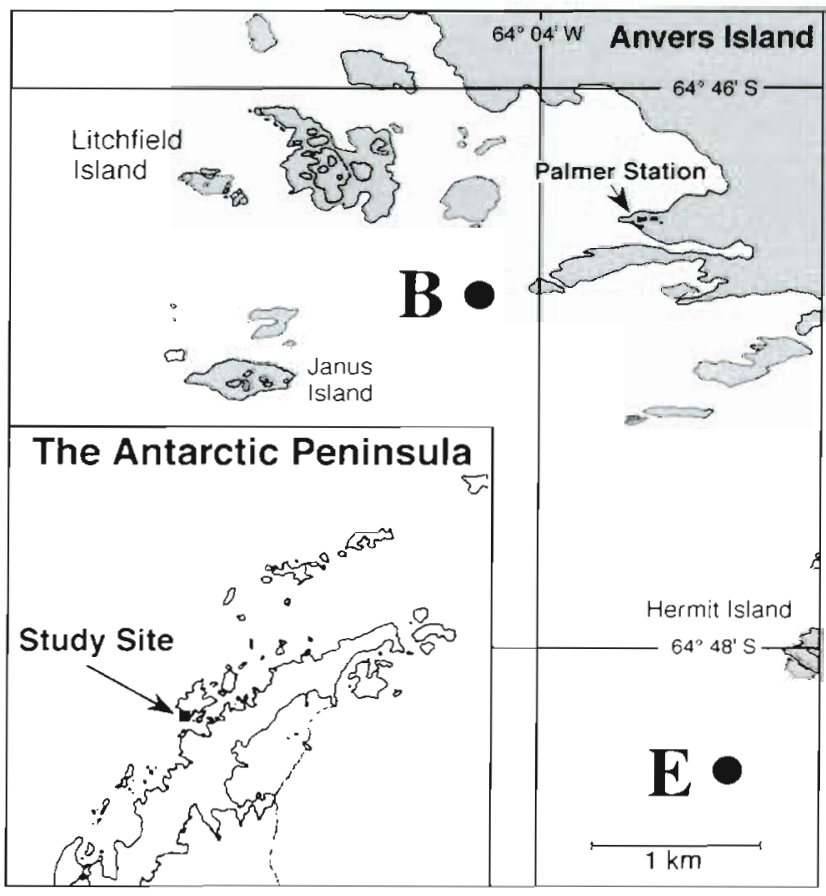

Fig. 1. Location of LTER sampling Stns $B\left(64^{\circ} 46.45^{\prime} S, 64^{\circ}\right.$ $\left.03.27^{\circ} \mathrm{W}\right)$ and $E\left(64^{\circ} 48.90^{\prime} \mathrm{S}, 64^{\circ} 02.43^{\prime} \mathrm{W}\right)$ with respect to Palmer Station and the Antarctic Peninsula (inset). Distance between Stns $B$ and $E$ is $\sim 3 \mathrm{~km}$ terns in phytoplankton communities of the Southern Ocean.

A high-resolution temporal data base was collected in shelf waters adjacent to Palmer Station, Antarctica for concurrent determinations of physical, biological and chemical parameters related to phytoplankton ecosystem dynamics during the austral spring/summer period of 1991 to 1994. This work was done as part of the Palmer Long-Term Ecological Research (LTER) program, a multidisciplinary program established to understand and model interactions between different marine trophic levels and with the variable chemical/optical/physical environments of the Southern Ocean (Ross \& Quetin 1992). Here, this highly resolved nearshore data base is used (1) to quantify the variability in phytoplankton biomass, in situ productivity and taxonomic composition over subseasonal, seasonal and interannual time scales, and (2) to elucidate mechanisms controlling these temporal patterns. These findings provide insights and advancements for ascertaining the differences between short-term variability and long-term trends in phytoplankton dynamics for diverse regions of the Southern Ocean.

\section{MATERIALS AND METHODS}

Sampling and physical measurements. Over the austral spring/summer period from November 1991 through January 1994, a total of 1140 discrete water samples were collected at the LTER Stns B and E (Fig. 1) for concurrent determinations of physical, optical, biological and chemical parameters related to phytoplankton ecosystem dynamics. Stn B is a shallow nearshore station $(-75 \mathrm{~m})$, while Stn $\mathrm{E}$ is a significantly deeper ( $280 \mathrm{~m}$ ) and more exposed station located on the northern edge of the Bismark Strait. The distance between Stns B and E is ca $3 \mathrm{~km}$. Water column sampling was conducted from a Mark V Zodiac ${ }^{\circledR}$ boat and, whenever possible, samples were collected within a few hours of solar noon. Daily air temperature, snow cover and average wind speed/direction measurements were taken at Palmer Station during the study period as part of a long-term database collected by the US National Science Foundation. Sea ice coverage was assessed by daily observations. A more detailed description of the sampling strategy for the 1991-1992 season, which was identical, with 1 exception, for the following 2 field seasons, is given by Moline \& Prézelin (1996).

The 1 exception between years is that water column density data is only available for the 1991-1992 season when 38 conductivity and temperature profiles were measured at Stns B and E using a SeaBird ${ }^{\circledast}$ CTD on a 
second Zodiac ${ }^{\circledR}$ described by Smith et al. (1992). The original reports of the findings are found in Smith et al. (1992) and Moline et al. (1996). The depth of the upper mixed layer (UML) based on the sigma-t $\left(\sigma_{t}\right)$ profiles was estimated using the formulation

$$
\max \left|\frac{\mathrm{d} \sigma_{1}}{\mathrm{~d} z}\right|
$$

(where $z=$ depth) which assumes the UML depth to be equal to the depth where the gradient in $\sigma_{\mathrm{t}}$ is maximal Like Mitchell \& Holm-Hansen (1991), we assume if the maximal $\sigma_{1}$ gradient was less than $0.05 \mathrm{~m}^{-1}$, then the water column was essentially well mixed to the bottom (ca $80 \mathrm{~m}$ at Stn B) or below the sampling depth $(100 \mathrm{~m}$ for $\operatorname{Stn} E$ ).

Phytoplankton pigmentation. Aliquots of all whole water samples were analyzed for the algal pigments using reverse-phase HPLC procedures detailed in Moline \& Prézelin (1996) for the 1991-1992 season and Wright et al. (1991) for the following 2 years. One liter samples were filtered on $0.4 \mu \mathrm{m}$ nylon $47 \mathrm{~mm}$ Nuclepore ${ }^{\oplus}$ filters and extracted in $3 \mathrm{ml} 90 \%$ acetone for $24 \mathrm{~h}$ in the dark at $-20^{\circ} \mathrm{C}$. Pigment separation was achieved with the aid of an Hitachi ${ }^{\otimes}$ L-6200A pump and an L-4250 UV/VIS variable wavelength detector $(436 \mathrm{~nm})$ equipped with a Waters ${ }^{\oplus}$ Radial-PAK C ${ }_{18}$ column $(8 \times 100$ mm; 5 um) during the 1991-1992 season and a Waters ${ }^{\circledR}$ Resolve $C_{18}$ column $(3.9 \times 300 \mathrm{~mm} ; 5 \mu \mathrm{m})$ for the following 2 seasons. Peak identities of algal extracts were determined by comparing their retention times with pure pigment standards Calibration studies comparing methods of Bidigare et al. (1989) and Wright et al. (1991) showed no significant quantitative differences for any of the pigments of interest. For the purposes of the present study, temporal/ spatial patterns are presented for chlorophyll a (chl a), an indicator of total phytoplankton biomass, and the phytoplankton group-specific pigments chlorophyll $b$ (chl b) for chlorophytes (Jeffrey 1974), fucoxanthin (Fuco) for diatoms (Wright \& Jeffrey 1987), alloxanthin (Allo) for cryptophytes (Gieskes 1983) and the sum of 19'-hexanoyloxyfucoxanthin (Hex) and 19'-butanoyloxyfucoxanthin (But) as a marker for chromophytesnanoflagellates (in the Antarctic primarily Phaeocystis pouchetii). While some species of Phaeocystis contain a significant amount of fucoxanthin (Buma et al. 1991), there is evidence to show that the contribution is low for Southern Ocean strains (Wright \& Jeffrey 1987, Vaulot et al. 1994, Bidigare et al. 1996). In order to estimate the respective contribution of each taxonomic group, multiple regression analyses were performed on the vertically integrated concentrations [surface to $0.1 \% Q_{P A R}$ (400 to $700 \mathrm{~nm}$ ) light level] of the taxonomic pigments against chl a (Gieskes et al. 1988, Everitt et al. 1990, Bustillos-Guzmán et al. 1995). The regression analyses for each year yielded the following results:
1991-1992: Chl $a=$

2.00 Fuco + 3.15 Allo + 1.99 (Hex + But $)+0.68 \mathrm{Chl} b$ $\left(r^{2}=0.99, p<0.001\right)$

1992-1993: Chl a =

1.54 Fuco + 2.92 Allo + 1.91(Hex + But $)+0.42 \mathrm{Chl} b$

$\left(\mathrm{r}^{2}=0.94, \mathrm{p}<0.001\right)$

1993-1994: Chl $a=$

1.30 Fuco + 3.49 Allo + 1.45 (Hex + But $)+0.50 \mathrm{Chl} b$ $\left(r^{2}=0.71, p<0.001\right)$

The lower $r^{2}$ for the 1993-1094 season may have been the result of photoadaptation, or change in the ratio of taxonomic pigment to chl $a$, that occurred within the phytoplankton groups over the comparitively longer sampling season. Other taxonomic pigments that would have contributed to the total chl $a$ and altered the regression were not detected during this study.

For each sampling date, the chl a associated with each taxonomic group (diatoms, cryptophytes, nanoflagellates, green algae) was computed using the regressions above from the concentration of its representative pigment (or group of pigments). Computed taxon-specific chl a concentrations were in turn used to estimate the contribution of each taxonomic group to the total biomass.

Surface and in-water $Q_{\mathrm{PAR}}$ measurements. Surface and in-water $Q_{p A R}$ (400 to $700 \mathrm{~nm}$ ) measurements made during the 1991-1992 season are detailed in Moline \& Prézelin (1996). For the 1992-1993 and 1993-1994 seasons, QpAR measurements were performed using an inwater Li-Cor ${ }^{*}$ LI-190SA quantum scalar irradiance sensor and a Li-Cor ${ }^{\otimes}$ LI-190SA reference sensor. In addition to irradiance profiles taken during sampling, incident $Q_{\text {PAR }}$ was recorded continuously every 5 min over the 3 yr period using a Li-Cor ${ }^{\circledR}$ LI-190SA. A comparison between data collected from the sensors at Palmer Station and those collected from the Zodiac ${ }^{(B)}$ sampling platform showed that $Q_{\text {PAR }}$ readings differed $<5 \%$. Intercalibration of the sensors between years showed a difference of $<1 \%$. In-water and reference light data were used to calculate the percent $Q_{P A R}$ at each sampling depth, which was assumed not to change over the course of a day. Percent $Q_{\text {PAR }}$ data were interpolated (linear interpolation of log-transformed data) vertically in the water column over $1 \mathrm{~m}$ intervals for primary production calculations (see below).

Photosynthesis-irradiance relationships and primary production calculations. Estimates of in situ primary production rates were derived from photosynthesis-irradiance $(P-I)$ relationships measured for 756 discrete water samples. The $P$-I procedures, detailed for the 1991-1992 season in Moline \& Prézelin (1996), were the same methods used for the following 2 seasons. Freshly collected whole water samples were incubated in laboratory blue-green light $Q_{P A R}$ photosynthetrons, using established radiolabelled $\mathrm{H}^{14} \mathrm{CO}_{3}$ 
uptake procedures (Prézelin et al. 1989, Prézelin \& Glover 1991). Blue-green light fields more closely mimic in-water spectral conditions in clear ocean waters and tend to release cells from artificial white light (or far-red) effects, which can reduce carbon uptake rates and photosynthetic quantum efficiencies (Prézelin et al. 1989, Schofield et al. 1991). Each discrete sample was exposed to 25 light levels up to $1500 \mu \mathrm{E} \mathrm{m}^{-2} \mathrm{~s}^{-1}$. Incubations times were kept to $90 \mathrm{~min}$ and incubation temperatures were controlled to within $0.2^{\circ} \mathrm{C}$ of in situ temperatures. It is possible that ultraviolet light (UV) inhibition effects on the in situ primary production, if present, were removed during the $Q_{\text {PAR }}$ incubation in the absence of UV radiation (Boucher \& Prézelin 1996ab). Thus, values reported here should be considered upper limit estimates of in situ rates of primary production in Antarctic coastal waters.

Non-linear curve fits for $P$-I data were calculated using the Simplex method of Caceci \& Cacheris (1984). Curve fitting provided the photosynthetic parameters $P_{\max }$ ( $\mathrm{mg} \mathrm{C} \mathrm{mg} \mathrm{chl} \mathrm{a}^{-1} \mathrm{~h}^{-1}$ ), the light-saturated photosynthetic potential $I_{\mathrm{k}}\left(\mu \mathrm{mol}\right.$ quanta $\left.\mathrm{m}^{-1} \mathrm{~s}^{-1}\right)$, an estimate of the minimum irradiance required to saturate photosynthesis; $\alpha$ [mg C mg chl $a^{-1} \mathrm{~h}^{-1}$ (umol quanta $\left.\left.\mathrm{m}^{-2} \mathrm{~s}^{-1}\right)^{-1}\right]$, the light limited photosynthetic efficiency; $\beta$ [(mg C mg chl $a^{-1} \mathrm{~h}^{-1}$ ( $\mu \mathrm{mol}$ quanta $\left.\mathrm{m}^{-2} \mathrm{~s}^{-1}\right)^{-1}$ ], the efficiency of photoinhibition; and $I_{1}$ ( $\mu$ mol quanta $\mathrm{m}^{-2}$ $\mathrm{s}^{-1}$ ), the irradiance threshold for the onset of photoinhibition. Estimates of the standard deviations for the $P-I$ parameters were calculated using the procedures described by Zimmerman et al. (1987). Discrete $P_{-} I$ relationships with estimated standard deviations of $>25 \%$ for $P_{\max }$ and/or $>30 \%$ for $\alpha$ were eliminated from this study. The effect was to reduce the size of the productivity data base by less than $10 \%$.

In addition to measuring the 'instantaneous' $P-I$ parameters, weekly determinations of the diel periodicity ( $3 \mathrm{~h}$ resolution) for each $P$ - $I$ parameter were performed at the surface and chl a maximum over the $3 \mathrm{yr}$ study in order to time-correct the instantaneous measurements and accurately determine daily rates of in situ primary production. The methods of determining diel periodicities of $P-I$ parameters and integrating these measurements into the daily rate calculations were detailed thoroughly in Moline \& Prézelin (1996). The resulting $P$-I parameters determined for every $2 \mathrm{~h}$ interval over the day were linearly interpolated at $1 \mathrm{~m}$ intervals with depth and combined with $Q_{P A R}$ for each meter (see above) for calculating primary production.

Interpolating light data and photosynthetic parameters over small depth interval $(1 \mathrm{~m})$ improved the accuracy of primary production estimates more than would have been achieved by employing more common trapezoidal integration procedures. Trapezoidal integration assumes a linear change of the integrated parameter between 2 consecutive depths. Such an assumption is reasonable for depth distribution of biological properties (i.e. photosynthetic parameters), but not for light attenuation which decreases log-linearly with depth. Our analyses (not given) show that trapezoidal integration procedures applied to even 5 to $10 \mathrm{~m}$ depth intervals can lead to a significantly higher estimation of production than would have been predicted with light fields interpolated for $1 \mathrm{~m}$ intervals.

Thus, we calculated primary production at each $1 \mathrm{~m}$ interval and then integrated over depth. In situ primary production at each meter for every $2 \mathrm{~h}$ interval over the day $[P(z, t)]$ was calculated, using the hyperbolic tangent model of Platt \& Gallegos (1980), such that

$$
P(z, t)=P_{\max }(z, t) \cdot \tanh \left(\frac{Q_{P_{A R}}(z, t)}{I_{k}(z, t)}\right)
$$

when $Q_{\mathrm{PAR}}(z, t)$, the measured integrated in situ irradiance for each $2 \mathrm{~h}$ interval, was less than $\mathrm{I}_{t}\left(z_{i} t\right)$ and

$$
\begin{aligned}
& P(z, t)= \\
& P_{\text {max }}(z, t) \cdot \tanh \left(\frac{Q_{\text {PAR }}(z, t)}{I_{k}(z, t)}\right) \cdot \exp \left[-\beta\left(Q_{\mathrm{PAR}}(z, t)-I_{t}(z, t)\right)\right]
\end{aligned}
$$

when $Q_{\text {PAR }}(z, t)$ was greater than $\mathrm{I}_{t}(z, t)$ (Neale \& Richerson 1987). Daily rates of in situ production were computed as the sum of the 12 daily 2 h intervals.

For intervening days where discrete samples were not taken, estimates of parameters used in the primary productivity calculations and pigmentation were derived by interpolation using exponential kriging methods (Spyglass ${ }^{\text {B }}$ Transform, Champaign, IL, USA). This method incorporates the measured light field when calculating estimates of primary productivity and does not assume a linear transition between sampling days. The primary assumption of this approach is that significant variability in biological parameters occurs on longer time scales than the daily fluctuation in the light field. This is a reasonable assumption given data collected during the 1991-92 season showed a maximum daily variation of 2 -fold in biomass and other biological parameters, while the daily $Q_{\mathrm{PAR}}$ light field varied a factor of 4 over the same time interval. Transmission of $Q_{\text {PAR }}$ through ice was held constant at $10 \%$, which was the average measured for the different ice conditions (i.e. pack, brash, or fast ice) observed at Stn B.

\section{RESULTS}

\section{Interannual and subseasonal variability in standing stock and water column dynamics}

The 1991-1992, 1992-1993 and 1993-1994 temporal contour plots of chl a biomass distribution, for both LTER Stns B and E, are compared in Fig. 2A \& B. With 


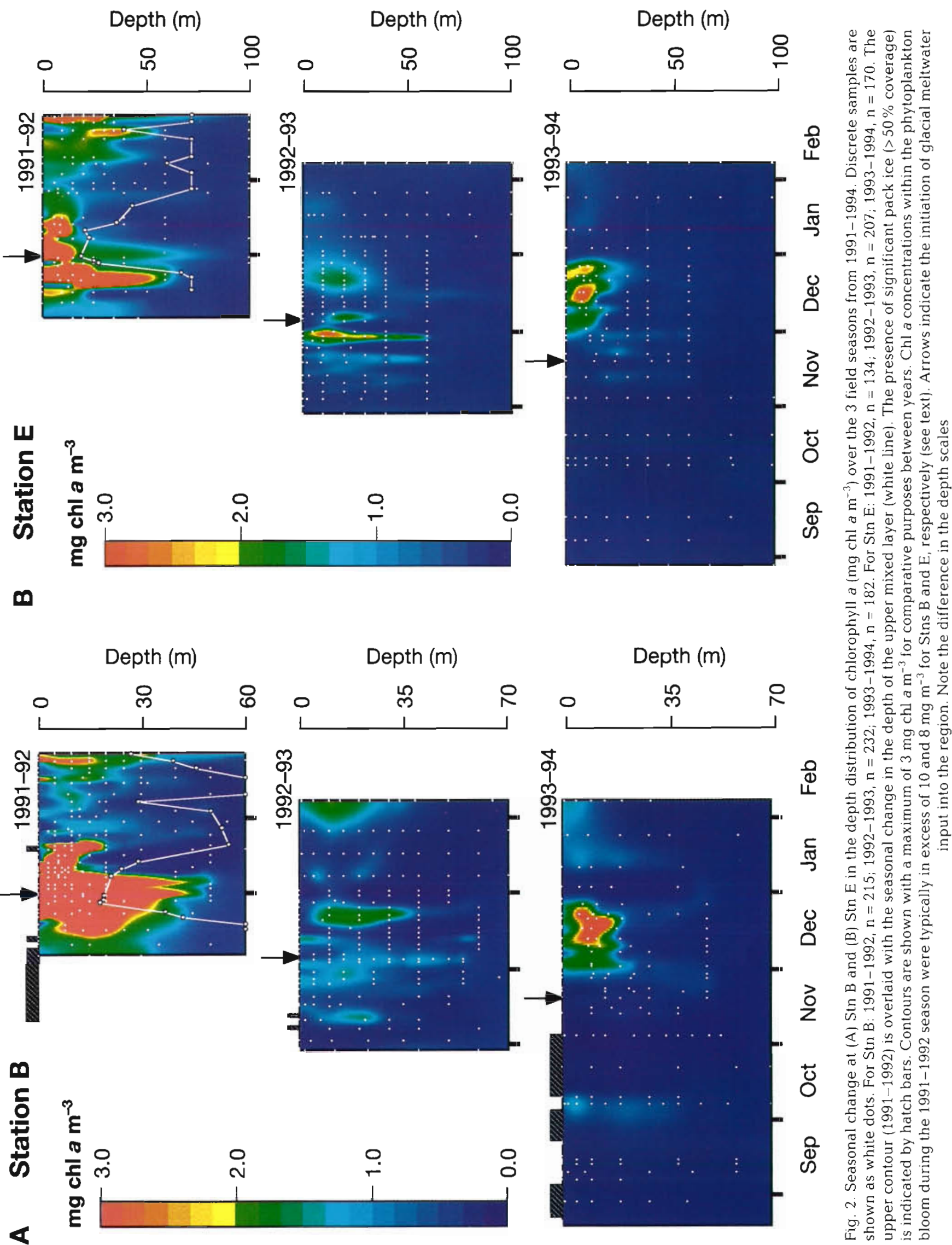


1 exception at Stn $E$ in 1992-1993, the annual peak biomass was observed in December of each year. Accumulated phytoplankton biomass was high in 1991-1992; low in 1992-1993; and moderate in 19931994. On subseasonal time scales in each year, there were periods of abrupt changes in water column phytoplankton biomass. In general, the magnitude of variability in chl a biomass measured within a few days within a given year was as great as the variability in chl a biomass compared for similar periods between years

\section{1-1992 field season}

This season was characterized by a large phytoplankton bloom immediately following the break-up of the local fast ice at Stn B (Fig. 2A, top). At the start of the sampling season, the 'seed' population that gave rise to the bloom was evident below the ice at Stn B (Moline \& Prézelin 1996, Moline et al. 1996), unlike the lower chl a biomass at Stn E which was ice free in early December 1991. The initiation of the bloom was coincident with an extended period of low wind stress (Fig. 3A) and water column stability in the absence of a pycnocline (Fig. 2). Although this has been shown previously for other regions (Ryther \& Hulbert 1960, Townsend et al. 1992), the specific importance of low wind stress for stability and the development of blooms is only occasionally emphasized (Sakshaug \& Slagstad 1992). Stabilization was enhanced by density stratification resulting from the input of glacial meltwater A comparison between the duration of daily average wind speeds $k<$ to $<25 \mathrm{~m}$ $\left.\mathrm{s}^{-1}\right)$ and the variance in the water column $\sigma_{t}$ revealed that extended periods of wind speeds below $12 \mathrm{~m} \mathrm{~s}^{-1}$ were the most significant determinant of water column stratification (Fig. 3B). The UML shallowed from $60 \mathrm{~m}$ to $10 \mathrm{~m}$ during the first $2 \mathrm{wk}$ of December (Fig. 2A \& $\mathrm{B}$, top), concentrating the developing bloom in the surface waters (Fig. 3C). Interestingly, high integrated chl a values were found when the UML depth was $>35 \mathrm{~m}$ (Fig. 3C), further illustrating that the bloom initiation occurred in the absence of a pycnocline. Peak chl a concentrations reached $29.21 \mathrm{mg} \mathrm{m}^{-3}$ at Stn B and $10.89 \mathrm{mg} \mathrm{m}^{-3}$ at Stn E, with concentrations from 3 to $5 \mathrm{mg} \mathrm{m}^{-3}$ extending down to a depth of ca $50 \mathrm{~m}$ at both stations. At the peak of the bloom, up to $75 \%$ of the total integrated chl a was below the $0.1 \% Q_{P A R}$ light level, suggestive of high sinking rates.

Although water column biomass was significantly higher at Stn B than at Stn E during the 1991-1992 bloom, there were pulsed events at Stn E when the integrated biomass was comparable between stations
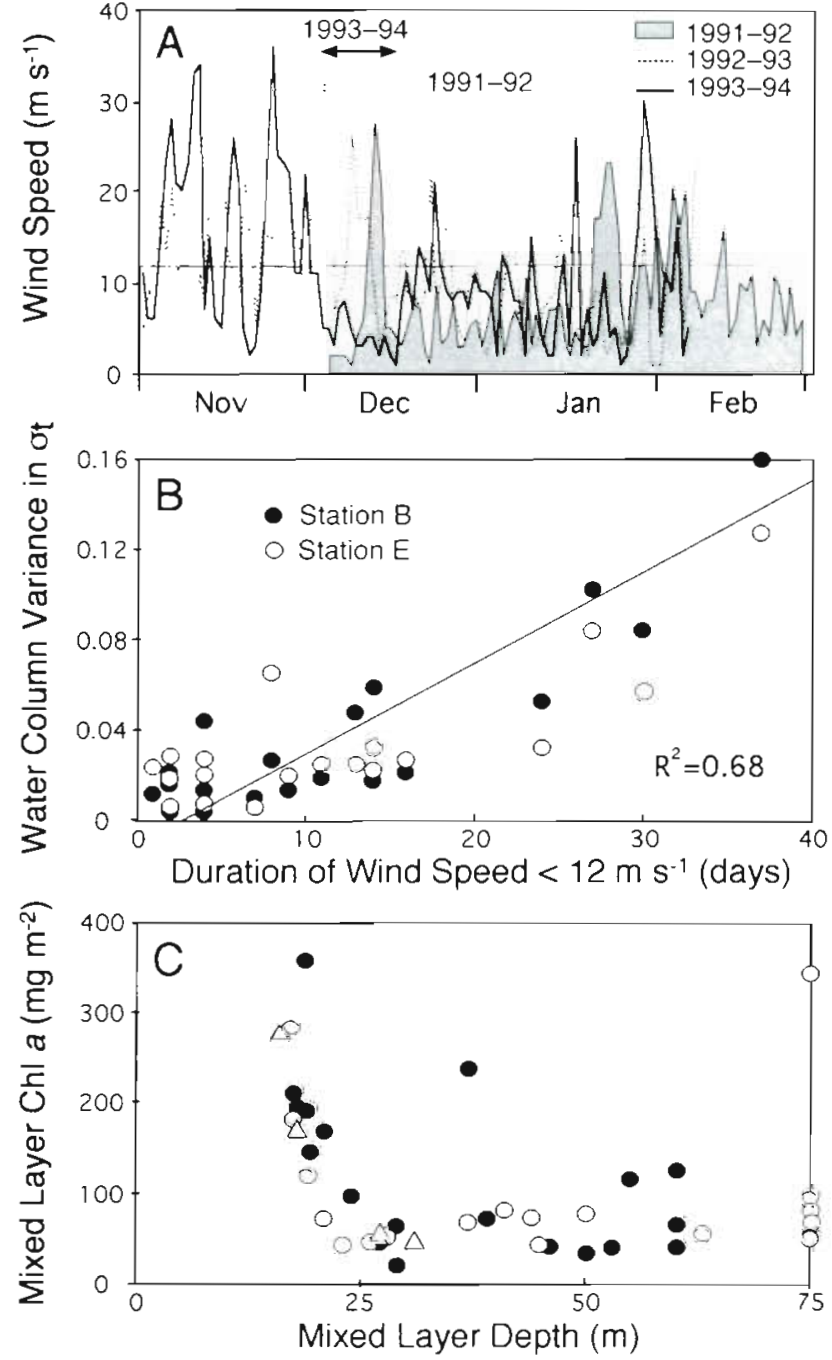

Fig. 3. Comparison of (A) average daily wind speed $\left(\mathrm{m} \mathrm{s}^{-1}\right)$ during the austral summer period from 1991 to $1994.12 \mathrm{~m} \mathrm{~s}^{-1}$ was found to be a significant wind speed threshold for water column stability (horizontal line; see text). The arrows represent 2 extended periods when wind speeds were below this threshold and blooms occurred (see Fig. 2). (B) Relationship between the duration of daily average wind speed less than $12 \mathrm{~m} \mathrm{~s}^{-1}$ and the variance in water column density $\left(\sigma_{1}\right)$ for Stns B and E during the 1991-1992 season. (C) Concentration of chl a within the mixed layer as related to depth of the mixed layer for Stns B and E during the 1991-1992 season. Symbols for Stns $B$ and $E$ are the same as in (B). For comparison, monthly mean values $(\Delta)$, derived from $\mathrm{chl} a$ and $\sigma_{t}$ profiles along the Antarctic Peninsula between December 1986 and March 1987, are presented (Mitchell \& HolmHansen 1991)

(Fig 2A \& B, top). These events occurred periodically at 7 to $8 \mathrm{~d}$ intervals and were found to be coupled to the tidal cycles (Fig. 4A). The tides at Palmer Station during December 1991 were primarily diurnal with solar (K1) and lunar (O1) constituents, similar to find- 
ings by $A$ mos (1993a). The maximum tide differential ranged from $\sim 0.4 \mathrm{~m}$ during neap tides [Julian Days (JD), 349 and 362] to $\sim 1.6 \mathrm{~m}$ during the spring tide (JD 357) (Fig, 4B). Because profiles were made near solar noon each day, the direction of the tidal flushing changed at the time of sampling over the season. From JDs 344 to 349 and 357 to 362 , the flow was from Stn E to B. Similarly, from JD 349 to 357 the flow was from Stn B to E. This tidal signal was also seen in the difference in the integrated biomass between stations (Fig. 4.B). As the flow from Stn B to E reached a maximum on JD 357, the large diatom bloom from Stn B was advected offshore and extended to Stn E with the difference in biomass signals between the stations reaching a minimum. Likewise, when the flow from $S$ tn $E$ to $B$ reach a maximum on JD 362 , water was pushed up against the coast and there was a maximum difference in the integrated biomass between stations. The tidal signal was also recorded in the differential in average surface temperatures between stations (Fig. 4C). When the difference in the biomass between Stns $E$ and $B$ was at a minimum, temperatures at both stations converged.

The accumulation of biomass at Stn B increased phytoplankton absorption (Schofield et al. 1994 , unpubl.) and surface waters warmed from $-1.2^{\circ} \mathrm{C}$ in early December to $+2^{\circ} \mathrm{C}$ at the peak of the bloom on JD 362 (Fig. 5A, top). With the tidal advection, this relatively warm water periodically extended out to $\operatorname{Stn} E$. increasing temperatures from $-0.5^{\circ} \mathrm{C}$ to $0.5^{\circ} \mathrm{C}$ (Fig $5 \mathrm{~B}$, top). Interesting to note was that during the period of surface stratification and stability in December 1991, there were periodic intrusions of warmer high-salinity water at depth. This may have been a result of tidal forcing and/or current patterns in the Bismark Strait advecting Circumpolar Deep Water (CDW), known to influence regions well inshore of the continental shelf break (Hofmann et al. 1993, Klink et al. 1994), into the study area.

In mid-January 1992, the bloom was advected from the area and replaced with a low biomass water column (Moline et al. 1996). The advection event occurred on a time scale shorter than the sampling frequency (every 2 to $3 \mathrm{~d}$ ) and, unlike the tidal advection, was too rapid to be detected from the changing biomass signals between $\mathrm{Stn} B$ and $\mathrm{E}$. The advection of a new water mass into the area was evident by the rapid warming of the entire water column at Stns $B$ and $E$

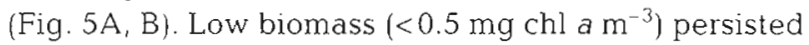
at both stations until the end of February when chl a concentrations increased in the presence of enhanced stratification (Fig. 2A, B). Further warming $\left(>1^{\circ} \mathrm{C}\right.$ ) of the water column in mid-February was coincident with high precipitation and increased runoff from the coast (Moline et al. 1996).
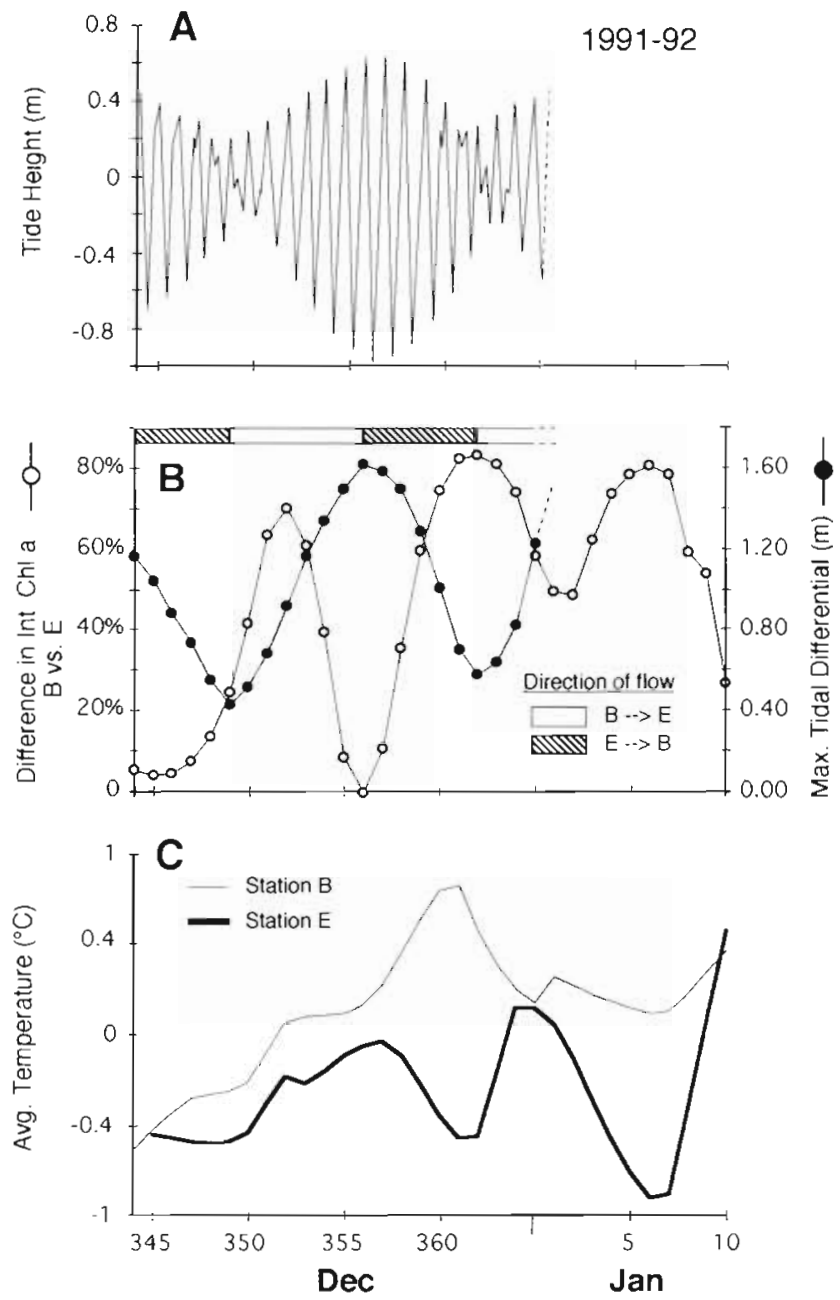

Fig. 4. (A) Tidal height (m) measured at Palmer Station from December 10 to 31, 1991 (JD 345-365). In (B), maximum tide differential $(m)$ derived from (A) is shown with the percent difference in the integrated (0 to $20 \mathrm{~m}$ ) chl a between Stns B and $E(1-E / B)$. Directions of tidal flow are shown for solar noon (time of sampling). (C) Difference between the average temperatures in the upper $10 \mathrm{~m}$ at Stns B and E from December 1991 to January 1992

1992-1993 field season

During this season, the region around the LTER nearshore stations was ice free and had been so for most of the year (Palmer Station Ice Observation Record) with the exception of 2 days in November at Stn B. In 1992-1993, spring or summer phytoplankton blooms were absent (Fig. 2A \& B, middle). Biomass concentrations were relatively low over the entire season with peak concentrations at Stn B in late December

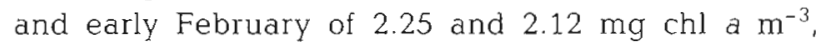
respectively. Peak standing crop at Stn E occurred in late November and was generally less coupled with 


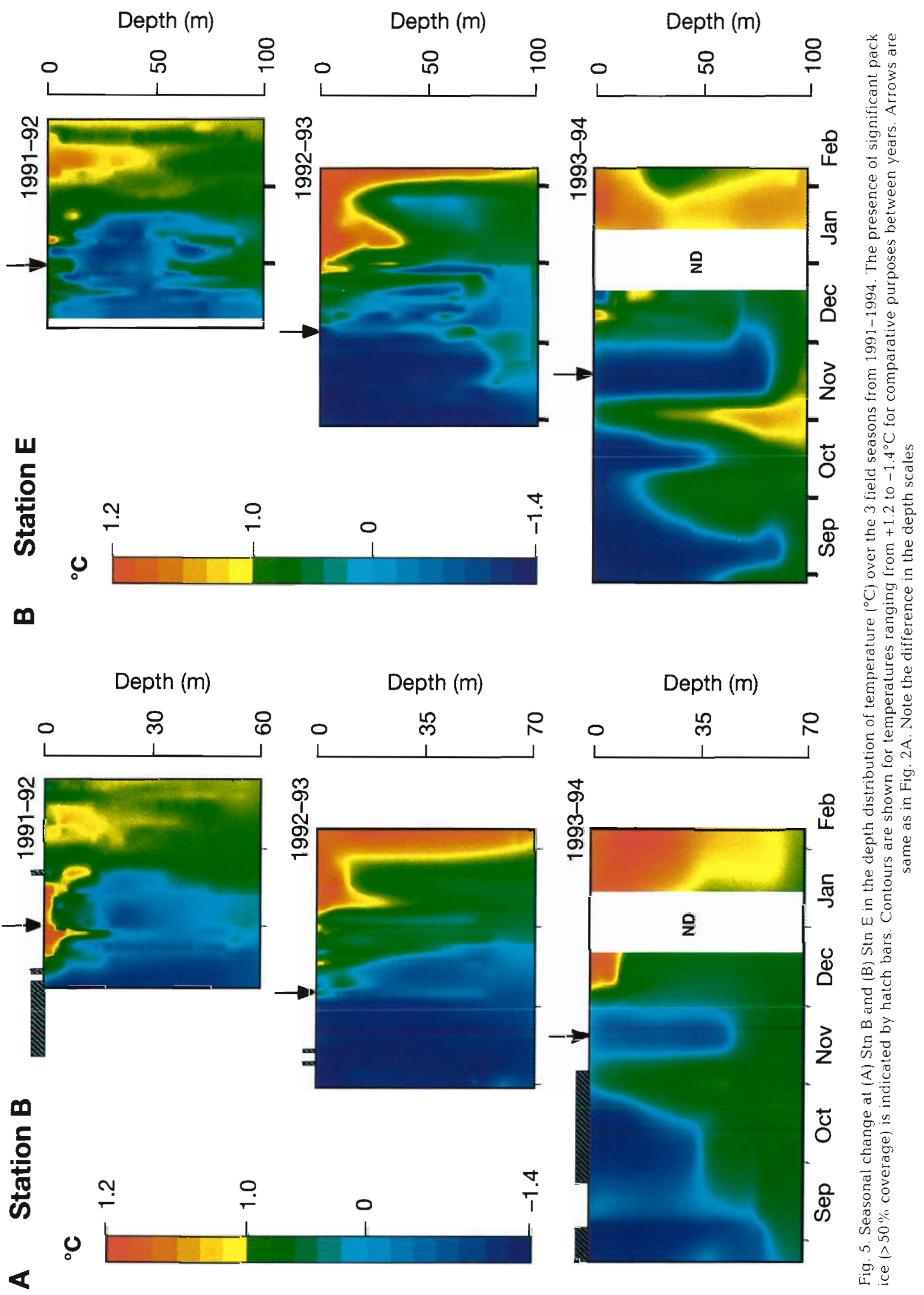




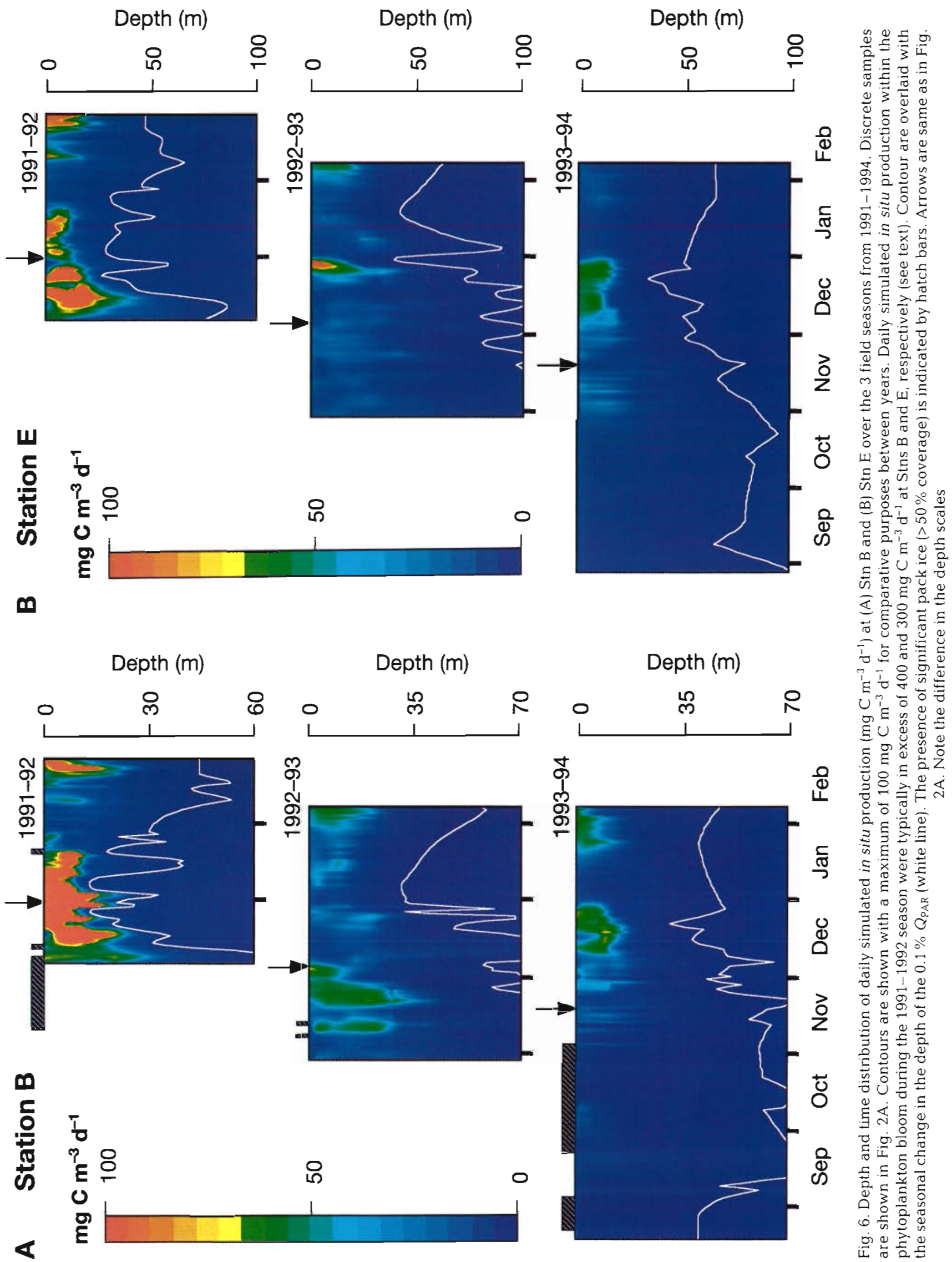


Stn B than during the 1991-1992 season. Vertical profiles routinely indicated uniform depth distributions of chl a concentrations at both Stns B and E, suggestive of significant vertical mixing. At the same time, water columns were generally isothermal (Fig. 5A \& B, middle) and coincident with average daily wind speeds in excess of $12 \mathrm{~m} \mathrm{~s}^{-1}$ for much of the season (Fig. 3A). Similar to the 1991-1992 season, there was a seasonal warming of the water column, however, surface temperatures during 1992-1993 were generally warmer than the previous year.

1993-1994 field season

During this season, sampling began in late August when heavy land-fast ice was a dominant feature at Stn B. The presence of the ice had a measurable cooling effect on the water column temperature profiles (Fig. 5A \& B, bottom). The gap in ice cover at Stn B in late September 1993 corresponded to a temperature increase in the water column, suggesting that advection of a different watermass was coupled to the ice break-up. During the late winter and early spring, biomass remained low, averaging $0.17 \mathrm{mg} \mathrm{chl} \mathrm{a} \mathrm{m}^{-3}$ (Fig. 2A \& B, bottom). There was an increase in chl $a$ measured at Stn B during the beginning of October that was not recorded at Stn E. It may have been the result of sampling disturbance of the highly concentrated ice algal communities. After the ice break-up in early November, biomass steadily increased at Stn B to a maximum of $4.91 \mathrm{mg} \mathrm{chl} a \mathrm{~m}^{-3}$ at the end of December. Although high winds, similar to those in 1992-1993, dominated most of the field season, the development of this small bloom corresponded to a $10 \mathrm{~d}$ period of low wind speeds in mid-December 1993 (Fig. 3A). As during the 1991-1992 season, the timing of surface warming was coupled to the increase in biomass (Fig. 5A \& B, bottom). Stn E showed similar temporal biomass distribution to Stn B. However, the overall concentrations at Stn $E$ were lower than at Stn B (Fig. 2A \& B, bottom). Like the 1991-1992 season, there were periodic fluctuations in the integrated biomass at both stations resulting from tidal forcing.

\section{Daily primary production}

Fig. 6 compares the estimated daily rates of in situ primary production as a function of depth for both Stn $B$ and $E$ during the 3 consecutive field seasons between 1991 and 1994. Not surprising, most of the time variability in in situ rates of daily primary production was closely coupled to variability in phytoplankton biomass (compare Figs. $2 \& 6$ ). The highest carbon fixation rates for all 3 field seasons (748 $\mathrm{mg} \mathrm{C} \mathrm{m}^{-3} \mathrm{~d}^{-1}$ ) were associated with the 1991-1992 bloom at Stn B. In the following season, maximum daily production was almost 6 -fold lower ( $130 \mathrm{mg} \mathrm{C} \mathrm{m} \mathrm{m}^{-3} \mathrm{~d}^{-1}$ ) and observed in near surface waters at Stn $E$, not $B$, in mid-December. Maximum production at Stn B in the 1992-1993 season

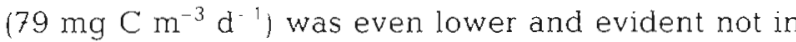
mid-December but in mid- to late November. In the last field season of 1993-1994, primary production once again peaked in December at both stations with the production at $\operatorname{Stn} B$ being higher than that at Stn $E$. Maximum rates of primary production, however, only reached $82 \mathrm{mg} \mathrm{C} \mathrm{m}^{-3} \mathrm{~d}^{-1}$ in December 1993, a value 9fold lower than that measured at the very same location at the same time of year but 2 yr earlier.

Interesting to note is that the depth of significant production shallowed in response to increased light attenuation. During the 1991-1992 bloom, the depth of the $0.1 \%$ isolume shallowed to $\sim 8 \mathrm{~m}$ and up to $70 \%$ of the water column primary production became light limited (Moline \& Prézelin 1996). Low light penetration persisted even after the demise of the bloom largely due to the input of highly attenuating particles associated with the runoff of glacial meltwater (Smith et al. 1992) typical for the spring/summer season (Shabika et al. 1977). The initiation of glacial runoff is indicated in all contour plots by arrows and occurred in late December 1991, in early December 1992, and in midNovember 1993. The input of glacial meltwater also significantly attenuated in-water light fields during December and January of the 1992-1993 season when chl a biomass was particularly low. Significant production during the late winter months of 1993 was restricted to surface waters largely due to the low daily surface irradiance at that time of the year and attenuation of light by ice cover

Seasonal variations in integrated water column biomass and areal rates of daily primary production are compared in Fig 7 It is clear that local biomass and primary production can be an order of magnitude higher for bloom years than non-bloom years. While light appeared to drive the day to day variation in production, the magnitude of seasonal and interannual production corresponded to the biomass variability. Total integrated biomass ( $\mathrm{mg} \mathrm{chl} \mathrm{a} \mathrm{m}^{-2}$ ) was significantly correlated to daily integrated primary production ( $\mathrm{mg} \mathrm{C} \mathrm{m} \mathrm{C}^{-2} \mathrm{~d}^{-1}$ ) over all 3 years (Fig. $8_{i} p<0.0001$ ). Although significant at these scales, the coupling between biomass and productivity has been found to be highly variable in relation to a number of environmental parameters. See Claustre et al. (1996) for a detailed discussion of the robustness of the relation. ship between chl a biomass and primary production within this temporal data base. Table 1 summarizes the seasonal and interannual variation in $Q_{P A R}$, areal bio- 
mass and the calculated in situ primary production on monthly time scales for the 3 yr study. Monthly mean biomass and total primary productivity for Stns B and E from 1991 to 1994 showed increases associated with the seasonal change in the light field.

\section{Phytoplankton community structure}

Seasonal and interannual variations in phytoplankton community composition are defined and analyzed here as changes in the percent of total depth integrated chl a that is statistically related to the depth integrated taxon-specific pigments. Contour plots of the temporal variability in euphotic zone phytoplankton community composition for both Stns B and $E$ for all 3 field seasons are given in Fig. 9. Where CTD casts were made available, we estimated the average $\sigma_{t}$ for the water column and plotted its variability over time for the 1991-1992 season. Initially apparent is that the patterns of phytoplankton community change are similar between stations for any given year but that the timing of these changes, which can occur abruptly, differs significantly between years.

Diatoms comprised over $70 \%$ of the initial biomass at Stn B for the 1991-1992 season (Fig. 9A). This dominance increased with the development of the bloom and peaked at over $95 \%$ at the height of the bloom. During the bloom, there was a rapid ( 1 wk) transition from this diatom community to one $90 \%$ dominated by cryptophytes. Cryptophytes remained at Stn B until the advection event occurred, at which time it was replaced with a mixed community of diatoms and Phaeocystis pouchettii, the dominant prymnesiophyte in the Southern Ocean (Bidigare et al. 1996). A similar pattern was found for Stn E in 1991-1992, although the duration of the cryptophyte dominance was longer (Fig, 9B). Chlorophytes were found to contribute little $(<10 \%)$ to the overall seasonal biomass.

This seasonal successional pattern was repeated for the 1992-1993 and 1993-1994 seasons at Stns B and E (Fig. 9A, B), despite the differences in physical forcing and changes in the magnitude of biomass. Late winter periods appeared to have a dilute 'seed' population of mixed diatoms and prymnesiophytes, with ca $5 \%$ cryptophytes. For all 3 seasons, cryptophytes increased their dominance to between 70 and $90 \%$ during the
Station B

Station E
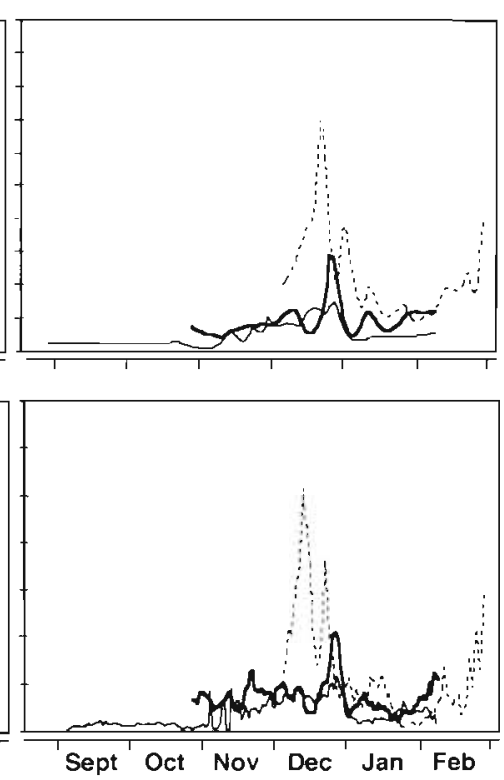

Fig. 7. Total integrated chl a and daily simulated in situ primary production for Stns $B$ and $E$ over the 3 field seasons from 1991-1994. Stn B was integrated to $60 \mathrm{~m}$ for 1991-1992 and $70 \mathrm{~m}$ for 1992-1994. The depth of integration for Stn E was $100 \mathrm{~m}$

summer period, followed by a mixed population similar to that at the beginning of the season.

The presence of ice appeared to determine the 'seed' phytoplankton community at the beginning of the growth season. Diatom communities in late spring/ early summer of 1991 and 1993, prior to the succession by cryptophytes, were comprised primarily of Coscinodiscus sp., the same genus associated with the ice communities earlier in both seasons (Schofield et al. 1994,

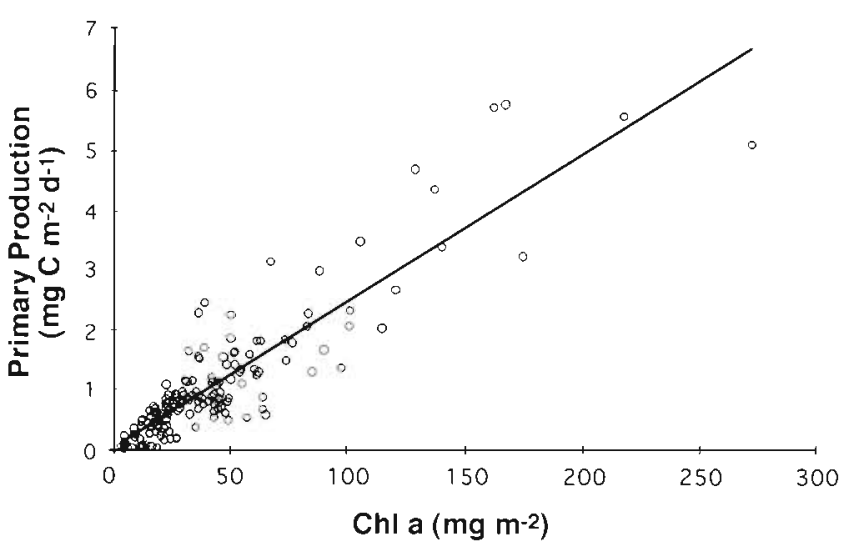

Fig. 8. Total integrated chl $a$ in the euphotic zone $10.1 \% Q_{\mathrm{PAR}}$ isolume) versus the daily simulated in situ production for Stns B and E over the 3 field seasons from 1991 to 1994. The best-fit linear regression is included $[P=0.025 \times \mathrm{Chl} \alpha+0.015$ $\left.\mathrm{r}^{2}=0.80, \mathrm{n}=156\right]$ 
Table 1. Monthly mean solar radiation (QPAR), biomass (chl a) and total primary production (PP) for LTER Stns B and E from 1991 to 1994 . Mean values are $\pm 1 \mathrm{SD}$

\begin{tabular}{|c|c|c|c|c|c|}
\hline \multirow[t]{2}{*}{ Year/month } & \multirow{2}{*}{$\begin{array}{c}Q_{P A R}\left(0^{+}\right)^{d} \\
\left(\mathrm{~mol} \mathrm{~m} \mathrm{~m}^{-2} \mathrm{~d}^{-1}\right)\end{array}$} & \multicolumn{2}{|c|}{ Stn B } & \multicolumn{2}{|c|}{$\operatorname{Stn} E$} \\
\hline & & Chl a (mg chl a m-2) & $P P\left(g \subset m^{-2}\right)$ & Chl a (mg chl a m-2) & $P P\left(g C \mathrm{~m}^{-2}\right)$ \\
\hline \multicolumn{6}{|l|}{ 1991-1992 } \\
\hline December & $48.6 \pm 12.7$ & $183.4 \pm 119.2$ & $78.12^{\mathrm{b}}$ & $178.9 \pm 71.1$ & 71.61 \\
\hline January & $28.9 \pm 11.4$ & $115.7 \pm 89.4$ & $40.61^{\mathrm{b}}$ & $74.9 \pm 29.9$ & 18.91 \\
\hline February & $28.0 \pm 11.5$ & $49.4 \pm 19.2$ & $20.72^{b}$ & $89.2 \pm 31.8$ & 25.76 \\
\hline \multicolumn{6}{|l|}{$1992-1993$} \\
\hline November & $27.5 \pm 8.7$ & $37.9 \pm 8.9$ & 34.80 & $31.8 \pm 6.8$ & 21.90 \\
\hline December & $33.3 \pm 9.7$ & $48.4 \pm 15.3$ & 20.15 & $61.6 \pm 33.3$ & 28.83 \\
\hline January & $39.6 \pm 13.7$ & $28.1 \pm 5.8$ & 12.09 & $41.7 \pm 12.1$ & 14.26 \\
\hline \multicolumn{6}{|l|}{ 1993-1994 } \\
\hline August ${ }^{c}$ & $6.1=3.1$ & $7.6 \pm 0.2$ & 0.62 & - & - \\
\hline September & $11.4 \pm 5.6$ & $14.5 \pm 7.0$ & 3.30 & $12.5 \pm 1.0$ & 2.70 \\
\hline October & $27.3 \pm 7.0$ & $18.1 \pm 12.7$ & 5.97 & $11.2 \pm 2.5$ & 1.55 \\
\hline November & $31.4 \pm 14.0$ & $18.7 \pm 11.0$ & 10.20 & $22.4 \pm 12.9$ & 12.60 \\
\hline December & $38.8 \pm 10.7$ & $51.0 \pm 13.9$ & 20.77 & $51.6 \pm 12.6$ & 24.18 \\
\hline January & $30.0 \pm 9.9$ & $25.8 \pm 7.0$ & 10.85 & $21.6 \pm 2.1$ & 9.92 \\
\hline
\end{tabular}

\section{A Station B

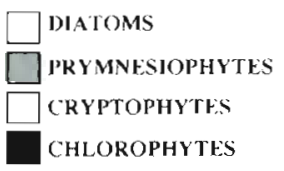

\section{$100 \%$

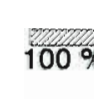

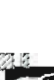

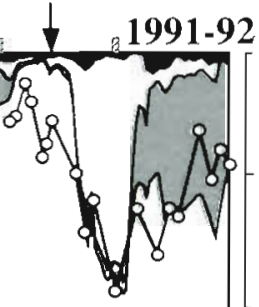

$1-92$

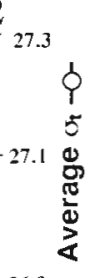

$1992-93$

2.69
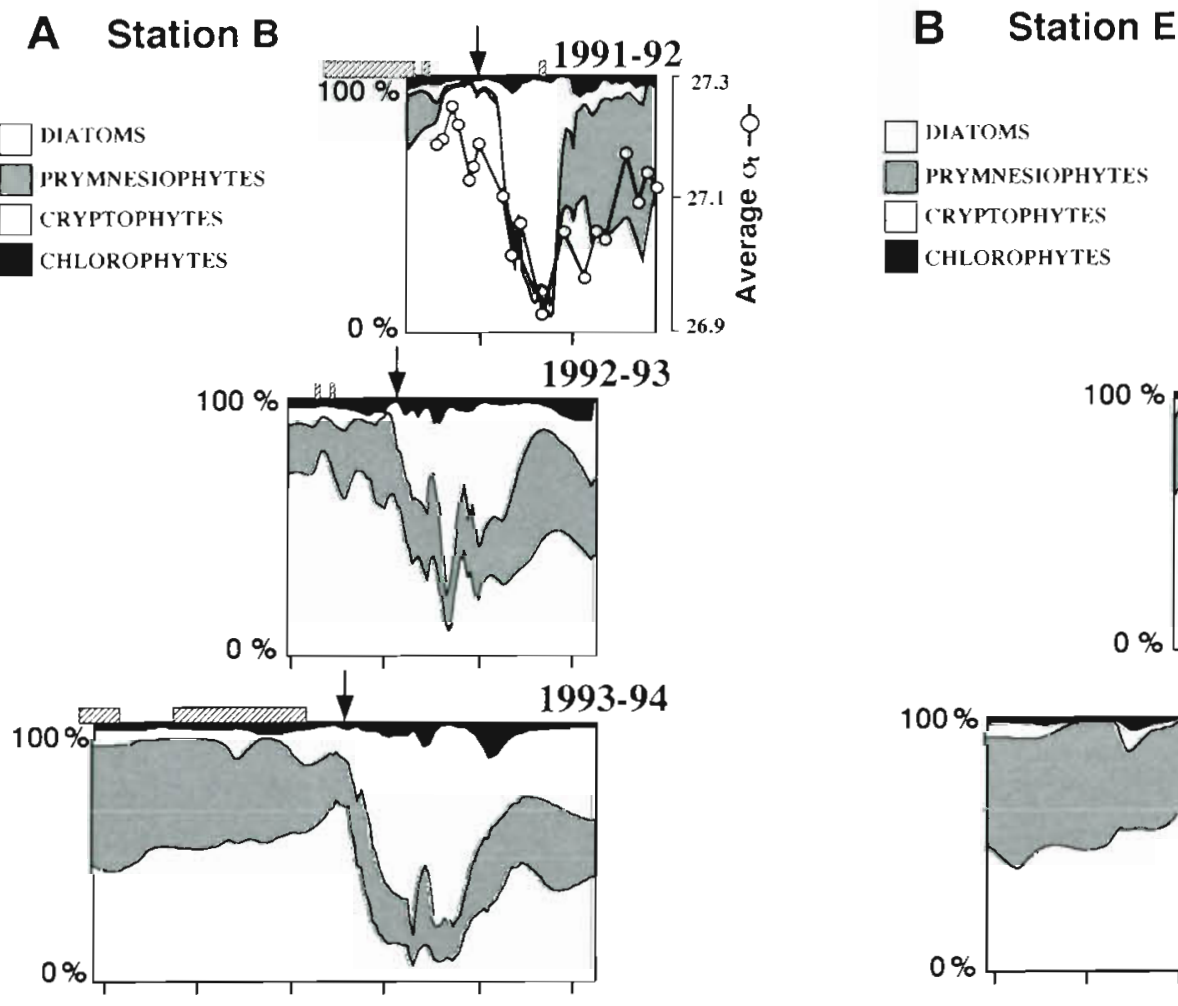

$100 \%$
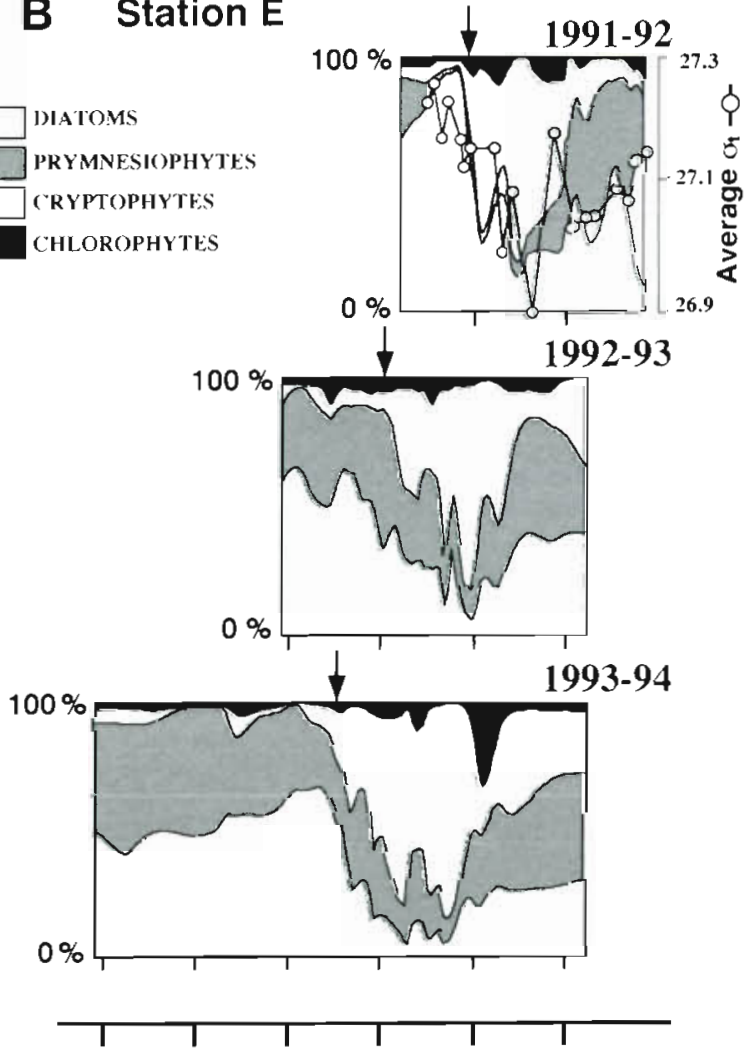

Sept Oct Nov Dec Jan Feb

Fig. 9. Seasonal change in the depth integrated percent composition of the 4 different phytoplankton groups represented at (A) Stn B and (B) Stn E over the 3 field seasons from 1991 to 1994. Overlaid on the 1991-1992 panel is the change in the average water column density $\left(\sigma_{t}\right)$ in the upper $50 \mathrm{~m}$. The presence of significant fast/pack ice (>50\% coverage) is indicated by hatch bars. 
Moline et al. 1996). During the 1992-1993 season, where there was no significant ice cover over the entire year, the diatom Corethron criophilum, known as a pelagic species (Sommer \& Stabel 1986, El-Sayed \& Fryxell 1993, Froneman et al. 1995), was dominant. This species was also the dominant diatom in the late summer for all 3 years.

\section{DISCUSSION}

The Palmer LTER is a multidisciplinary program which seeks to understand and model predictive interactions between different marine trophic levels and the chemical, optical and physical environments of the Southern Ocean. One area of focus is to define the patterns and control of primary production, especially as related to spatial and temporal distributions of populations representing trophic structures. The 1991-1994 data presented here represents the first 3 field seasons of the time-series studies. Starting up a long-term research program in a remote and environmentally extreme area, with relatively little background data, required much attention to both design of the field program and intensive data collection in order to assure the ability to eventually distinguish between natural short-term variability and long-term trends due to natural cycles (i.e. ice coverage) or unnatural environmental perturbations brought on by global climate change (i.e. global warming, ozone diminution). The resulting nearshore data base has already been used (1) to document the 1991-1992 variability in surface biological, optical, chemical and physical properties in the region (Moline et al. 1996), (2) to illustrate the impact the 1991 bloom had on water column chemistry (Moline \& Prézelin 1994), (3) to show that instantaneous measurements of primary production, if uncorrected or improperly corrected for daytime periodicities in carbon fixation, were unreliable predictors of production on longer time scales even if the water column was sampled every few days (Moline \& Prézelin 1996), and (4) to quantify the variability, and sources of variability, in the photosynthetic light utilization indexes ( ${ }^{*}$ ) (Claustre et al. 1996) and maximum quantum yield (Schofield et al. 1994, unpubl.), and the consequences for remote sensing of in situ rates of primary production for coastal waters of the Southern Ocean. Here we present, for the first time, the interannual variations in phytoplankton biomass, primary production and phytoplankton community structure, with an emphasis on illustrating the physical forcing functions underlying the interannual and subseasonal variations. The outcome of the present analyses is a better understanding of phytoplankton community dynamics in Antarctic coastal waters and insights into which phytoplankton markers might be most suitable for detecting ecological change on time scales longer than a few years.

\section{Interannual variability in phytoplankton biomass and photosynthesis is equivalent to seasonal variability}

In Fig. 10, we summarize the seasonal range of variability in integrated water column biomass from temporal studies in Antarctic coastal waters. At any given location, chl a biomass can vary by more than 2 orders of magnitude on subseasonal time scales, with the South Orkney Islands along the Palmer Peninsula and McMurdo Sound being the more extreme examples (Fig. 10A). The only multiple-year record providing integrated water column biomass, other than the present study, has shown interannual variability (Fig. 10B) to be significantly smaller (only 2.3-fold) than the range of seasonal variability (Fig. 10A) (Whitaker 1982). This result has led to the notion that summer phytoplankton blooms are a predictable repeated annual event for Antarctic coastal waters (Smith et al. 1995). While comparatively similar magnitude and variability in the annual standing stock were found for this study (Fig. 10), significantly higher interannual variation was measured for Stns B and E (6.6-fold), suggesting a less predictable yearly pattern. While most of the biomass accumulation and primary production occurred during the months of maximum solar insolation (Fig. 7. Table 1), the difference in the insolation between years varied a maximum of only $3.3 \%$ and, therefore, cannot account for the range in peak biomass and primary production signals measured between years for this study.

\section{Close coupling exists between wind stress, water column stability and bloom development}

Water column stability was found to be the primary mechanism controlling the variability in biomass, a result found for other areas of the Southern Ocean (Smith \& Nelson 1985, Mitchell \& Holm-Hansen 1991, Mitchell et al. 1991). Water column stability, in turn, appeared to be driven by the seasonal variability in wind (Fig. 3), with the input of fresh water and thermal stratification during the summer months enhancing the stability (Moline et al. 1996).

The strong coupling between wind stress, water column stability and biomass accumulation was most evident during the 1991-1992 season. Wind stress was low for an extended period during this season, resulting in the shallowing of the UML and increased stratification. The duration (days) of low wind speeds was 


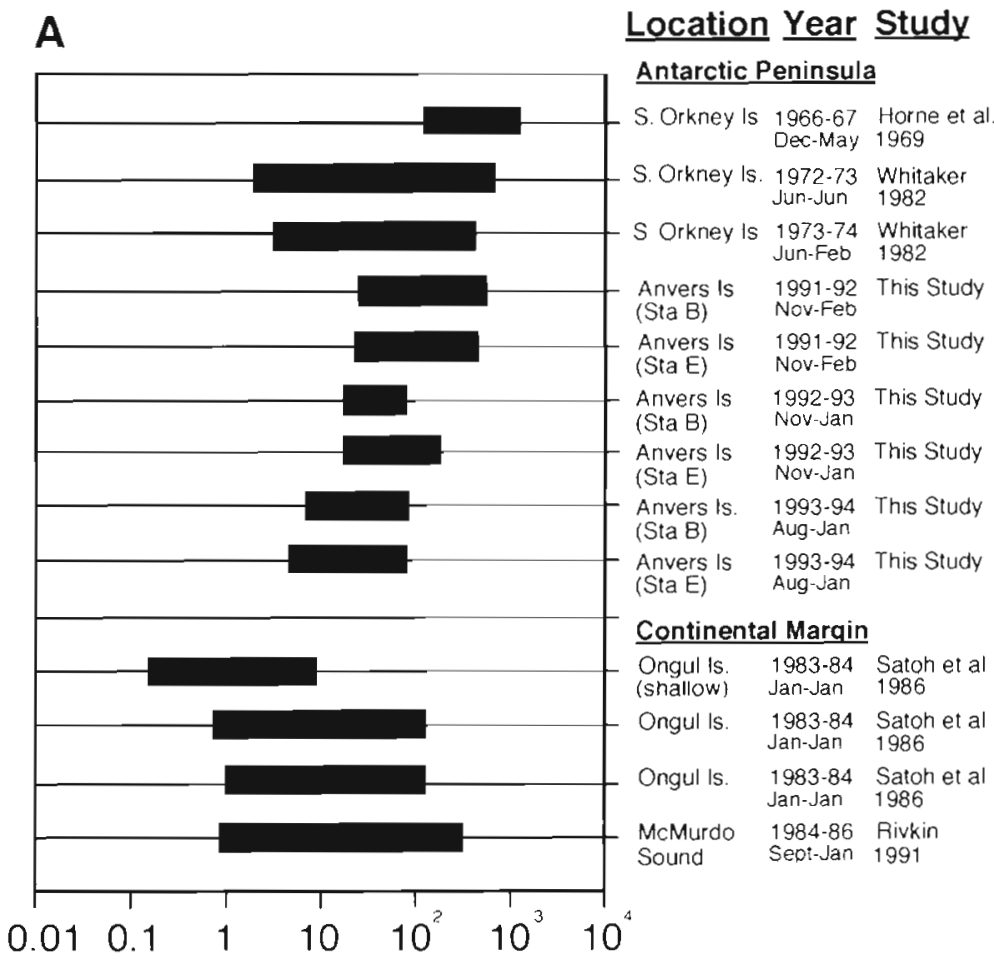

B

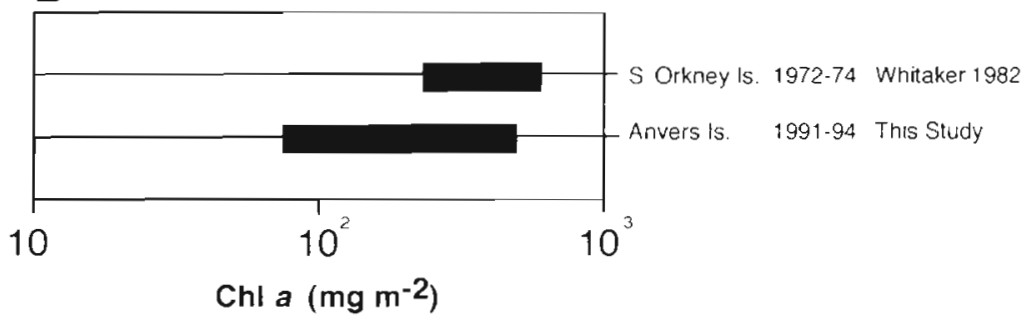

Fig. 10. Variability in the range of (A) intra-annual and (B) peak interannual biomass for this study and other temporal studies in coastal Antarctic regions

correlated with the depth of the UML, with the threshold for 'low' wind speeds of $<12 \mathrm{~m} \mathrm{~s}^{-1}$ showing the highest significance $(p<0.0001$; Fig. 3B). The shallowing of the UML and stratification maintained phytoplankton in the upper euphotic zone and the major diatom bloom developed. The non-linear relationship between the UML and biomass accumulation for this study (Fig. $3 \mathrm{C}$ ) is in close agreement with previous findings in other regions in the Southern Ocean (Mitchell et al. 1991, Nelson \& Smith 1991. Helbling et al. 1995), illustrating the requirement of stabilization for bloom development. On a seasonally integrated scale, the influence of wind on the variability in biomass is evident. Seasonal average wind speeds for the 1991-1992, 1992-1993, and 1993-1994 seasons were $7.96,10.58$, and $10.52 \mathrm{~m} \mathrm{~s}^{-1}$, respectively, with corresponding average integrated standing stocks of 76.2 . 39.23 , and $24.32 \mathrm{mg} \mathrm{chl} \mathrm{a} \mathrm{m}^{-2}$
The influence of wind on the formation of blooms has also been shown for other regions of the Southern Ocean. For iceedge blooms in the marginal ice-zone of the northwestern Weddell Sea, after examining the influences of ice meltwater, light, trace metals, and grazing pressures, Lancelot et al. (1993) concluded that strong wind conditions $\left(>14 \mathrm{~m} \mathrm{~s}^{-1}\right.$ ) were the primary determinant for bloom development even during the summer months of the highest solar insolation Recent analyses of remotely sensed biomass in the Ross Sea have shown that the large annual spring bloom coincides with typically low wind speeds for the entire area (K. Arrigo pers. comm.). Additionally, for areas of high sustained winds (i.e. Terra Nova Bay), there is a delay in the development of phytoplankton blooms until the average wind speeds drop below a certain threshold.

\section{Tidal forcing results in high daily variability between stations on space scales of 2 to $6 \mathrm{~km}$}

There was strong coherency between Stns $B$ and $E$ in the annual and monthly integrated biomass $\left(\mathrm{r}^{2}=0.86\right)$ and primary production $\left(r^{2}=0.84\right)$ (Table 1 ). This could be considered probable given that both stations are nearshore and influenced by the timing and magnitude of springtime glacial ice melt, which releases large quantities of fresh water into local surface waters, and strong episodic wind events that affect the entire Palmer region (Moline \& Prézelin 1996, Moline et al. 1996). However, as the period of integration decreased, the correspondence between the stations decreased (Fig. 7). This may partially be due to advection events which occurred on time scales of less than 1 mo. In addition to wind driven advection, advection resulting from the summer flow of fresh water from land, and possible influence of current patterns in the Bismark Strait, there was a strong tidal influence (Fig. 4)

Tidal advection of different water masses has been documented for the Palmer Station area (Amos 1993a), however, the influence of this phenomenon on temporal patterns of phytoplankton biomass and primary production has not been shown. During the spring tide, where the tide differential is maximum, the sampling time was found to be critical. Given the maximal flush- 
ing measured on JD 357, the integrated biomass at Stn $E$ in the most productive upper $20 \mathrm{~m}$ would range

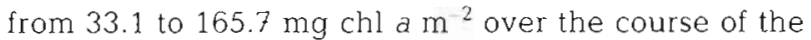
day, showing characteristics of both the inshore bloom waters and the less productive Bismark Strait waters, at least $3 \mathrm{~km}$ on either side of the station. This 5 -fold variation in the daily signal also has implications for spatial sampling, which in the Southern Ocean is often on scales larger than the lateral watermass movement due to tidal forcing (Smith \& Nelson 1985, Huntley et al. 1991, Waters \& Smith 1992).

\section{Consistent annual pattern in the development of cryptophyte-dominated phytoplankton is determined by the timing of the glacial meltwater runoff}

Given the high seasonal and interannual variability in the biomass and productivity responding to the fluctuating meteorological and hydrographic conditions during this study, similar variability for other aspects of phytoplankton dynamics might be expected. This was not the case, however, and a consistent and repeated annual pattern in phytoplankton succession was found. Cryptophyte dominance for all 3 seasons was found to be timed to the melt of the local snow cover and the initiation of glacial meltwater input into this coastal region (Fig. 9A, B). The percent dominance of cryptophytes was highly correlated to the density change in the water column $\left(r^{2}=0.57, p<0.001\right)$, further suggesting that the mechanism for this transition was the seasonal change in salinity. This is in good agreement with temperate regions, where this class is often associated with brackish water environments (Prézelin \& Bozcar 1986).

A number of other 'low' salinity environments in the Antarctic that have also been shown to be dominated by cryptophytes. Buma et al. (1992) found cryptophytes contributed over $95 \%$ of the total biomass in the low salinity waters (Tréguer et al. 1991) of a retreating marginal ice zone in the Weddell-Scotia Confluence area. Cryptophytes were also shown to increase with decreasing salinity during the summer months in the confluence of the Bellingshausen and Weddell Seas, along the Antarctic Peninsula (Mura et al. 1995). In the Ellis Fjord, McMinn \& Hodgson (1993) documented the dominance of cryptophytes coinciding with the high summer input of fresh water. In the perennially ice-covered lakes of the Dry Valleys, cryptophytes are found to dominate the phytoplankton community (Lizotte \& Priscu 1992). These populations, however, are rarely seen below the low salinity surface layer beneath the ice, even though nutrients are often depleted in this layer ( $M$. Lizotte pers. comm.).

\section{Best marker for longer term changes in ecosystem dynamics may be the timing and pattern of seasonal changes in phytoplankton community composition}

Given cryptophyte populations respond to changes in water column salinity, variations in the timing, duration and the quantity of the annual fresh water input may be reflected in the taxonomic changes in the phytoplankton community. Air temperature records showed that the day on which average temperature exceeded the freezing point was progressively earlier with each year (JD 333, 316 and 309 for the 3 years respectively). The number of days that temperatures were above freezing during the summer months also increased with each year. This is in agreement with both the timing of the onset of glacial melt and the duration of the cryptophyte dominance for each successive year (Fig. 9A, B). The average timing and magnitude of cryptophyte dominance at Stns $B$ and $E$ in relation to the mean air temperature is summarized for 1991-1994 in Fig. 11. The initiation of cryptophyte dominance is timed to the average air temperature exceeding the freezing point and the variability in this dominance is highest in December, where the timing of glacial melting changes from year to year (Fig 9A, B) The variability in the percent cryptophytes decreased in January, when the populations were established in the region (Fig. 11). By February, water column salinity returned to pre-meltwater conditions (Fig. 9A, B) and cryptophytes showed a marked decrease.

A statistically significant warming trend $\left(2\right.$ to $\left.3^{\circ} \mathrm{C}\right)$ for the mid-Antarctic Peninsula over the past 50 yr has been established (King 1994, Stark 1994), with potential effects on both sea-ice dynamics (Weatherly et al. 1991, Murphy et al. 1995) and glacial melting From these long-term trends and the results of our study, one may hypothesize that a shift in community composition has been occurring over the past decades with increasing dominance of cryptophytes in the coastal regions of the Southern Ocean. Although long-term data sets of phytoplankton seasonal successional are scarce, the few that have been collected suggest a changing trend in the community composition. A 24 yr study (1970 to 1993) in Paradise Bay has found a significant reduction in the abundance of diatoms and an increase in cryptophytes and other phytoflagellates (Ferreya \& Tomo 1979, G. Ferreya pers. comm.). A taxonomic study by Krebs (1983) sampling from 1972 to 1974 near Stn B found only diatoms (unlike our study for 1991 to 1994) and the cell numbers were highly correlated to chl a concentrations, suggesting low abundances of ather phytoplankters. More recently, a 4 yr study (1990 to 1993) near the South Shetland Islands found dramatic decreases in the abundance of diatoms and a 


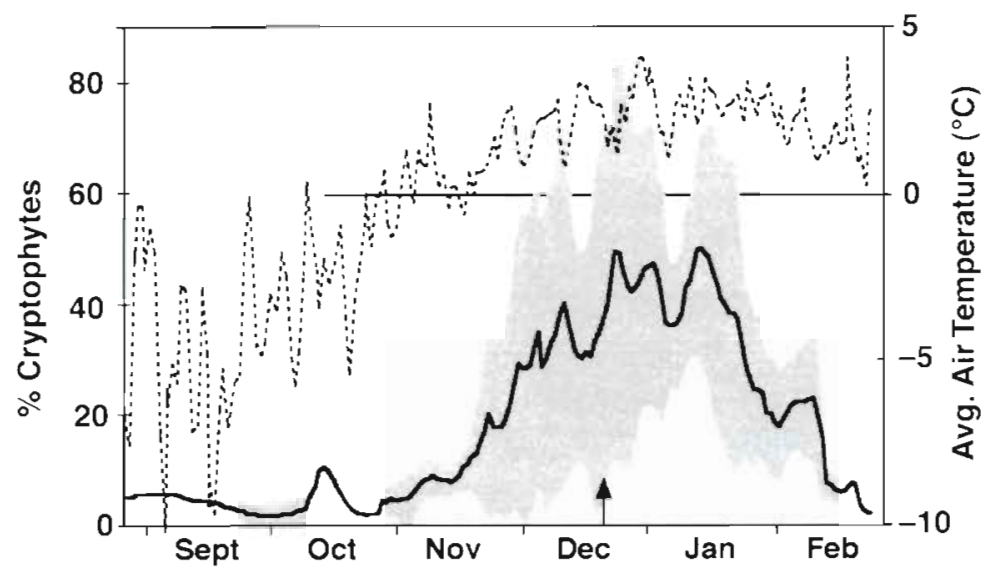

Fig. 11. Seasonal change in the mean percent contribution of cryptophytes to the total integrated biomass at Stns B and E from 1991-1994. Shaded area represents one standard deviation from the mean. The mean air temperature at Palmer Station for the study period is also shown. The vertical arrow indicates summer solstice elucidate long-term environmental change in the Southern Ocean, the use of moorings should perhaps be more seriously considered for future studies, despite the inevitable logistic problems associated with deployment. Notwithstanding the high temporal variability in biomass and associated production, one of the most surprising results of work presented here was the consistent annual successional pattern of the local phytoplankton communities influenced by the presence of sea ice and the seasonal input of meltwater from surrounding glaciers. These findings suggest that seasonal succession may be a better predictor of long-term environmental change than traditional biomass and productivity indices, which we have shown here to be highly variable on a subseasonal to interannual time scales. corresponding increase in cryptophytes and other phytoflagellates (Villafañe et al, 1995). A decrease in the surface salinity was recorded over this time (Amos 1993b), however, authors rejected the notion that these small hydrographic changes could have any significant effect on taxonomic composition. Whether or not these studies are taken as evidence for environmental change, they do imply a connection. Long-term trends in the community composition, especially during the peak growing season, may have significant influences on other trophic levels in the ecosystem (Bird \& Karl 1991), and therefore may be an important consideration for future studies and data interpretation. As monitoring of taxonomic change, as well as meteorological and hydrographic parameters, continues near Palmer Station as part of the LTER program, perhaps a more definitive answer will emerge.

\section{Conclusion}

Our highly resolved 3 yr data set quantifies the large seasonal and interannual variability in biomass and primary production for Antarctic coastal waters, and shows a close linkage to physical forcing in the local region. Wind stress, ice coverage, the timing of ice breakup, freshwater input and advection were all found to contribute to the high variability in the magnitude and temporal distribution of phytoplankton in these highly productive environments. Variability appeared to be high whether the time scale of interest was $1 \mathrm{~d}$ or $3 \mathrm{yr}$ This apparent time-independent variability illustrates the need to increase the resolution of temporal sampling to better quantify the short-term variability and the mechanisms driving that variability. If the goal is to
Acknowledgements. N. Boucher, B. Bozcar, T. Diem, T Evens, B. Golden, P. Handley, R. Jovine, H. Matlick, T. Newberger, S. Roll, K. Seydel, K. Scheppe, O. Schofield, J. Standish, B. Sullivan, T. Westerberry and the ASA personnel at Palmer Station are acknowledged for their assistance in data collection during the 3 field seasons. We thank R. Bidigare and $M$. Ondrusek for generously providing HPLC training and pigment standards. D. Karentz is thanked for providing tide data. H. Claustré is especially acknowledged for his assistance in data analyses and valuable insights, discussion and comments. This study was supported by National Science Foundation grant DPP 90-901127 to B.P. This is Palmer LTER publication number 96 .

\section{LITERATURE CITED}

Amos AF (1993a) RACER: the tides at Palmer Station. Ant J US 28:162-164

Amos AF (1993b) AMLR program: interannual variability in the Elephant Island surface waters in the austral summer. Ant J US 28:201-204

Bidigare RR, Schofield O, Prézelin BB (1989) Influence of zeaxanthin on quantum yield of photosynthesis of Synechococcus clone WH.7803 (DC2). Mar Ecol Prog Ser 56: $177-188$

Bidigare RR, Iriarte JL, Kang SH, Ondrusek ME, Karentz D, Fryxell GA (1996) Phytoplankton: quantitative and qualitative assessments. In: Ross R, Hotmann E, Quetin L [eds] Foundations for ecosystem research in the western Antarctic peninsula region. Antarctic Research Series, American Geophysical Union, Washington, DC (in press)

Bienati NL, Comes RA (1971) Variacion estacional de pigmentos fotosinteticos en aguas Antarcticas. Contribucion del instituto antartico Argentio 109:4-22

Bird DF, Karl DM (1991) Massive prasinophyte bloom in northern Gerlache Strait. Ant J US 26:152-154

Boucher NP. Prézelin BB (1996a) An ın situ biological weighting function for UV inhibition of phytoplankton carbon fixation in the Southern Ocean. Mar Ecol Prog Ser 144: $223-236$

Boucher NP, Prézelin BB (1996b) Spectral modeling of UV inhibition of an in sıtu Antarctic primary productıon usıng 
a newly derived biological weighting function. Photochem Photobiol 64:407-418

Buma AGJ, Bano N, Veldhuis MJ, Kraay GW (1991) Comparison of the pigmentation of two strains of the prymnesiophyte Phaeocystis sp. Neth J Sea Res 27:137-182

Buma AGJ, Gieskes WWC, Thomsen HA (1992) Abundance of Cryptophyceae and chlorophyll b containing organisms in the Weddell-Scotia Confluence area in the spring of 1988. Polar Biol 12:43-52

Bustıllos-Guzmán J, Claustre H, Marty JC (1995) Specific phytoplankton signature and their relationship to hydrographic conditions in the coastal northwestern Mediterranean Sed. Mar Ecol Prog Ser 124:247-258

Cacecl MS. Cacheris WP (1984) Fitting curves to data. Byte 9 $340-362$

Claustre H, Moline MA, Prézelin BB (1996) Sources of var1ability in the photosynthetic cross section for Antarctic coastal waters. J Geophys Res (in press)

De Baar HJW, de Jong JTM, Bakker DCE, Loescher BM, Veth C. Bathmann U. Smetacek V (1995) Importance of iron for plankton blooms and carbon dioxide drawdown in the Southern Ocean. Nature 373:412-415

Domanov MM, Lipski M (1990) Annual cycle of chlorophyll a and primary production of phytoplankton in Admiralty Bay (Antarctica). Pol Arch Hydrobiol 37:471-478

El-Sayed SZ, Fryxell GA (1993) Phytoplankton. In: Friedmann IE (ed) Antarctic microbiology. Wiley-Liss, New York, p $65-122$

Everitt DA, Wright SW, Volkman JK, Thomas DP, Lindstrom EJ (1990) Phytoplankton community compositions in the western equatoral Pacific dotrrmined from chlorophyll and carotenoid pigment distribution. Deep Sea Res 37 $975-997$

Ferreyra GA, Tomo AP (1979) Contribucion del instituto antartico Argentio 264:150-184

Froneman PW, MCQuaid CD, Perissinotto R (1995) Bıgeographic structure of the microphytoplankton assemblages of the south Atlantic and Southern Ocean during austral summer. J Plankton Res 17:1791-1802

Gieskes WWC (1983) Dominance of cryptophyceae during the phytoplankton spring bloom in the central North Sea detected by HPLC analysis of pigments. Mar Biol 75:179-185

Gieskes WWC, Kraay GW, Nontji A, Setiapermana D, Sutomo (1988) Monsoonal alteration of a mixed and a layered structure in the phytoplankton of the euphotic zone of the Banda Sea (Indonesia): a mathematical analysis of algal pigment fingerprints. Neth J Sea Res 22:123-137

Helbling EW, Villafañe VE, Holm-Hansen O (1995) Variability of phytoplankton distribution and primary production around Elephant Island, Antarctica, during 1990-1993. Polar Biol 15:233-246

Hofmann E, Lipphardt BL, Smith DA, Locarnini RA (1993) Palmer LTER: hydrology in the LTER region. Ant J US 28: $209-211$

Holm-Hansen O, Mitchell BG, Hewes CD, Karl DM (1989) Phytoplankton blooms in the vicinity of Palmer Station, Antarctica. Polar Biol 10:49-57

Holm-Hansen O. Mitchell BG (1991) Spatial and temporal distribution of phytoplankton and primary production in the western Bransfield Strait region. Deep Sea Res 38:961-980

Horne AJ, Fogg GE, Eagle DJ (1969) Studies in situ of the primary production of an area of inshore Antarctic Sea. J Mar Biol Ass UK 49:393-405

Huntley M, Karl DM, Niiler P, Holm-Hansen O (1991) Research on Antarctic Coastal Ecosystem Rates (RACER): an interdisciplinary field experiment. Deep Sea Res 38: $911-941$
Jeffery SW (1974) Profiles of photosynthetic pigments in the central North Pacific Ocean. Mar Biol 37:33-37

King JC (1994) Recent climate variability in the vicinity of the Antarctic Peninsula. Int J Climatol 14:357-369

Klink JM, Smith DA, Smith RC (1994) Hydrography in the LTER region during August and September 1993. Ant J US 29:219-221

Krebs WN (1983) Ecology of neritıc marine diatoms, Arthur Harbor, Antarctica. Micropaleontology 29:267-297

Lancelot C, Billen G, Veth C, Becquevort S, Mathot S (1991.a) Modelling carbon cycling through phytoplankton and microbes $1 \mathrm{n}$ the Scotia-Weddell Sea area during sea ice retreat. Mar Chem 35:305-324

Lancelot C, Billen G, Veth C, Becquevort S, Mathot S (1993) Factors controlling phytoplankton ice-edge blooms in the marginal ice-zone of the northwestern Weddell Sea during seas ice retreat 1988: fleld observations and mathematical modelling. Polar Biol 13:377-387

Lancelot C, Veth C, Mathot S (1991b) Modelling ice-edge phytoplankton bloom in the Scotia-Weddell sea sector of the Southern Ocean during spring 1988. J Mar Syst 2 $333-346$

Lizotte MP, Priscu JC (1992) Photosynthesis-irradiance relationships in phytoplankton from the physically stable water column of a perennially ice-covered lake (Lake Bonney, Antarctica). J Phycol 28:179-185

Mathot S, Dandols JM, Lancelot C (1992) Gross and net prinary production in the Scotia-Weddell Sea sector of the Southern Ocean during spring 1988. Polar Biol 12 321-322

McMinn A, Hodgson D (1993) Summer phytoplankton succession in Ellis Fjord, eastern Antarctica. J Plankton Res $15: 925-938$

Mitchell BG. Brody EA, Holm-Hansen O, McClain C, Bishop $J$ (1991) Light limitation of phytoplankton biomass and macronutrient utilization in the Southern Ocean. Limnol Oceanogr 36:1662-1677

Mitchell BG, Holm-Hansen O (1991) Observations and modeling of the Antarctic phytoplankton crop in relation to mixing depth. Deep Sea Res 38:981-1007

Moline MA. Prézehn BB (1994) Palmer LTER: impact of a large diatom bloom on macronutrient distribution in Arthur Harbor during austral summer 1991-1992. Ant J US 29(5):217-219

Moline MA, Prézelin BB (1996) High-resolution time-series data for primary production and related parameters at a Palmer LTER coastal site: implications for modeling carbon fixatıon in the Southern Ocean. Polar Biol (in press)

Moline MA, Prézelin BB, Schofield O, Smith RC (1996) Temporal dynamics of coastal Antarctic phytoplankton: environmental driving forces and impact of a 1991-1992 summer diatom bloom on the nutrient regimes. In: Battaglia $B$, Valencia J, Walton DWH (eds) Antarctic communities. Cambridge University Press, Cambridge (in press)

Mura MP, Satta MP, Agusti S (1995) Water-mass influences on summer Antarctic phytoplankton biomass and community structure. Polar Biol 15:15-20

Murphy EJ, Clarke A, Symon C, Priddle J (1995) Temporal variation in Antarctic sea-ice: analysis of a long term fastice record from the South Orkney Islands. Deep Sea Res 42:1045-1062

Neale PJ, Richerson PJ (1987) Photoinhibition and the diurnal variation of phytoplankton photosynthesis. I. Development of a photosynthesis-irradiance model from studies of in situ responses. J Plankton Res 9:167-193

Nelson DM, Smith WOJ (1991) Sverdrup revisited: critical depths, maximum chlorophyll levels, and the control of 
Southern Ocean productivity by the irradiance-maing regime. Limnol Oceanogr 36:1650-1661

Platt T, Gallegos CL (1980) Modeling primary productivits: In: Falkowski PG (ed) Primary production in the sea. Henum Press, New York, p 339-362

Prézelin BB, Bozcar B (1986) Molecular bases of cell absorption and fluorescence in phytoplankton: potential applications to studies in optical oceanography. In: Round F, Chapman D (eds) Progress in phycological research. Biopress Ltd; Bristol 4:349-465

Prézelin BB, Glover HE (1991) Variability in time/space estimates of phytoplankton biomass and productivity in the Sargasso Sea. J Plankton Res 13S:45-67

Prézelin BB, Glover HE, VerHoven B, Stemberg DK, Matlick HA, Schofield O, Nelson NB, Wyman U, Campbell L (1989) Blue-green light effects on licht-limited rates of photosynthesis: relationship to pigmentation and productivity estimates from the Sargasso Sea. Mar Ecol Prog Ser $54: 121-136$

Rivkin RB (1991) Seasonal patterns of planktonic production in McMurdo Sound, Antarctica. Am Zool 31:5-16

Ross RM, Quetin LB (1992) Palmer long-term ecological research (LTER): an overvicw of the 1991-1992 season. Ant J US 27:235-236

Ryther JH, Hulbert EM (1960) On winter mixing and the vertical distribution of phytoplankton. Limnol Oceanogr 5: $337-338$

Sakshaug E, Slagstad D, Holm-Hansen O (1991) Factors controlling the development of phytoplankton blooms in the Antarctic Ocean - a mathematical model. Mar Chem 35: $259-271$

Sakshaug E, Slagstad D (1992) Sea ice and wind: effects on primary productivity in the Barents Sea. AtmosphereOcean 30:579-591

Satoh H, Wantanabe K, Kanda H, Takahashı E (1986) Seasonal changes of chlorophyll a standing stocks and oceanographic conditions under fast ice near Syowa Station, Antarctrca 1983/84. Antarctic Rec 30:19-32

Scharek R, Smetacek V, Fahrbach E, Gordon LI, Rohardt G, Moore $S$ (1994) The transition from winter to early spring in the eastern Weddell Sea, Antarctica: plankton biomass and composition in relation to hydrography and nutrients. Deep Sea Res 41:1231-1250

Schofield O. Moline MA, Prézelin BB (1994) Photoadaptation in a coastal phytoplankton bloom and impact on the radiation utilization efficiency for carbon fixation. Ant J US 29:214-216

Schotield O, Prézelin BB. Smith RC, Stegmann PM, Nelson NB, Lewis MR, Baker KS (1991) Varability in spectral and nonspectral measurements of photosynthetic light utilization efficiencies. Mar Ecol Prog Ser 78:253-271

Shabica SV, Hedgpeth JW, Park PK (1977) Dissolved oxygen and $\mathrm{pH}$ increases by primary production in the surface water of Arthur Harbor, Antarctica, 1970-1971. In: Llano GA (ed) Adaptations within intarctic ecosystems. Gulf, Houston, p 83-97

Smetacek V, Scharek R, Gordon LI, Eicken H, Fahrbach $E_{\text {, }}$ Rohardt G. Moore S (1992) Early spring phytoplankton

This article was submitted to the editor blooms in ice platelet layers of the southern Weddell Sea, Antarctica. Deep Sea Res 39:153-168

Smith RC, Baker KS, Fraser WR, Hofmann EE, Karl DM, Klink JM, Quetin LB, Prézelin BB, Rorr RM, Trivelpiece WZ, Vernet M (1995) The Palmer LTER: a long-term ecological research program at Palmer Station, Antarctica. Oceanography $8: 77-86$

Smith RC, Baker KS, Handley P. Newberger T (1992) Palmer LTER program: hydrography and optics within the peninsula grid, zodiac sampling grid during the 1991-1992 field season. Ant J US 27:253-255

Smith WOJ, Nelson DM (1985) Phytoplankton bloom produced by a receding ice edge in the Ross Sea: spatial coherence with the density field. Science 277:163-166

Sommer U, Stabel HH (1986) Near surface nutrient and phytoplankton distribution in the Drake Passage during early December. Polar Biol 6:107-110

Stark P (1994) Climate warmıng in the central Antarctıc Peninsula area. Weather 49:215-220

Townsend DW, Keller MD, Sieracki ME, Ackleson. SG (1992) Spring phytoplankton blooms in the absence of vertical water column stratification. Nature 360:59-62

Tréguer $P$, Lindner L, Bennekom AJ, van Panouse M, Leynaert A, Jacques $G$ (1991) The production of biogenc silica in the Weddell-Scotia Seas measured by using radiotracer ${ }^{3 /} \mathrm{Si}$. Limnol Oceanogr 36:1217-1227

Turner D, Owens NJP (1995) A biogeochemical study in the Bellingshausen Sea: overview of the STERNA 1992 expedition. Deep Sea Res 42:907-932

Vaulot D, Birrein JL, Marie D, Casotti R, Veldhuis MJW, Kraay GW, Chrétiennot-Dinet MJ (1994) Morphology. ploidy, pigment compoistion, and genome size of cultured strains of Phaeocystis (Prymnesiophyceae). J Phycol 30 $1022-1035$

Villafañe VE, Helbing EW. Holm-Hansen O (1995) Spatial and temporal varability of phytoplankton biomass and taxanomic composition around Elephant lsland, Antarctica, during the summers of 1990-1993. Mar Biol 123:677-686

Waters KJ, Smith RC (1992) Palmer LTER: a samplıng grid for the Palmer LTER program. Ant J US 27:236-239

Weatherly JW, Walsh JE, Zwally HJ (1991) Antarctic sea ice variatjons and seasonal air temperature. $J$ Geophys Res 96:15119-15130

Whitaker TM (1982) Primary production of phytoplankton off Signy Island, South Orkneys, the Antarctic. Proc R Soc Lond 214:169-189

Wright SW, Jeffrey SW (1987) Fucoxanthin pıgment markers of marine phytoplankton analysed by HPLC and HPTLC Mar Ecol Prog Ser 38:259-266

Wright SW, Jeffrey SW, Mantoura RFC, Llewellyn CA, Bjørnland T, Repeta D. Welschmeyer N (1991) Improved HPLC method for analysis of chlorophylls and carotenoids from marine phytoplankon. Mar Ecol Prog Ser 77:183-196

Zimmerman RC, SooHoo JB, Kremer JN, D'Argenio DZ (1987) Evaluation of variance approximation techniques of non-linear photosynthesis-irradiance models. Mar Biol 95: $209-215$

Manuscript first received: May 20, 1996

Revised version accepted: September 24, 1996 